Western University

Scholarship@Western

2016

\title{
Climatic Cycles Recorded in Glacially Influenced Rhythmites of the Gowganda Formation, Huronian Supergroup
}

Tim S. Howe

The University of Western Ontario, thowe3@uwo.ca

Patricia L. Corcoran

The University of Western Ontario, pcorcor@uwo.ca

Fred Longstaffe

The University of Western Ontario, flongsta@uwo.ca

Elizabeth A. Webb

The University of Western Ontario, ewebb5@uwo.ca

R Gerhard Pratt

The University of Western Ontario, gpratt2@uwo.ca

Follow this and additional works at: https://ir.lib.uwo.ca/earthpub

Part of the Geology Commons, and the Geophysics and Seismology Commons

Citation of this paper:

Howe, Tim S.; Corcoran, Patricia L.; Longstaffe, Fred; Webb, Elizabeth A.; and Pratt, R Gerhard, "Climatic Cycles Recorded in Glacially Influenced Rhythmites of the Gowganda Formation, Huronian Supergroup" (2016). Earth Sciences Publications. 16.

https://ir.lib.uwo.ca/earthpub/16 
Page 1 of 50

1 6

\section{Climatic cycles recorded in glacially influenced rhythmites of the} Gowganda Formation, Huronian Supergroup

\author{
5 Department of Earth Sciences, The University of Western Ontario, London, Ontario, N6A 5B7, \\ T. S. Howe*, P. L. Corcoran, F. J. Longstaffe, E. A. Webb, R. G. Pratt \\ Canada \\ *Corresponding author (e-mail: thowe3@uwo.ca)
}

8

9

0

1

12

3

4


16 Abstract: The Gowganda Formation of the 2.45-2.2 Ga Huronian Supergroup contains glacially-

17 induced, varve-like rhythmites that potentially preserve a detailed record of climatic conditions

18 during the Paleoproterozoic Era. Four rhythmic couplet thickness records were measured at two

19 outcrops near Wharncliffe, Ontario for the purpose of time-series analysis. The couplets, which

20 range from $1-32 \mathrm{~mm}$ thick, are composed of alternating layers of siltstone and claystone. Time-

21 series analysis of the couplet thickness records using the MTM Toolkit of Mann and Lees (1996)

22 consistently revealed periodicities in the range of 2.2-2.9 couplets per cycle, which is consistent

23 with climatic cycles such as the quasi-biennial oscillation (QBO) and the El Niño Southern

24 Oscillation (ENSO) observed in modern times. This periodicity suggests that the rhythmic

25 couplets represent annual deposits (i.e. varves). Evidence for the presence of cycles at 3.0-4.9

26 couplets, 6.6-6.9 couplets, 8.8-9.2 couplets, 22.8 couplets, and 30.1-31.0 couplets were also

27 observed in some couplet thickness records; however the presence of these longer term cycles

28 was inconsistent from site to site.

30 Keywords: Huronian Supergroup, Gowganda Formation, varves, rhythmites, Paleoproterozoic,

31 MTM Toolkit, time-series analysis 


\section{Introduction}

33 Clastic rhythmites are subaqueous sediment couplets that are deposited in horizontal layers on a

34 periodic basis (Bramlette, 1946; Reineck and Singh, 1972). The couplets composing a rhythmite

35 generally consist of a coarse-grained layer, predominantly composed of fine sand or coarse silt,

36 and a fine-grained layer, which is generally composed of fine silt or clay (Williams, 2000).

37 Rhythmite development may be predominantly influenced by depositional environments and

38 processes, which is the case for tidalites and turbidite deposits, or mainly by climatic conditions

39 at the time of deposition, particularly if they are formed in association with deglaciation. De

40 Geer (1912) was the first researcher to describe rhythmites that form annually as a result of

41 deglaciation, introducing the term "varve" to describe a couplet. Early work on varves found in

42 glacial lakes in eastern Canada noted that the summer, coarse-grained layers were substantially

43 thicker than the winter, fine-grained deposits (Antevs, 1925). However, each layer comprising a

44 varve is not necessarily homogenous, as shown in a later investigation of varves in Lake Barlow-

45 Ojibway, Ontario, Canada (Agterberg and Banerjee, 1969). The authors subdivided the winter

46 layer into a lower turbidite deposit overlain by a clay layer that rained out from suspension. More

47 recently, varves have been defined as containing two or more laminal layers that repeat annually

48 (Ojala et al., 2012). Ultimately, the thickness of individual varves in glacially-influenced

49 environments is related to the annual influx of sediment to a regional basin, which is influenced

50 by the annual rate of glacial meltwater discharge (Delaney, 2005).

51 Hughes et al. (2003) conducted a small-scale spectral analysis of 256 rhythmites within the upper

52 Gowganda Formation from a location they referred to as the Wharncliffe argillite. The present 
53 study expands upon the work of Hughes et al. (2003) by examining four rhythmite sequences

54 from two rock outcrops within the upper Gowganda Formation in order to: (1) determine

55 whether climate forcing can be identified, and if found, (2) compare climatic periods across all

56 four rhythmite records. We employ high resolution spectral analysis using the multitaper method

57 of Mann and Lees (1996) to identify consistent periodicities associated with climatic forcing

58 influenced rhythmite formation, implying that individual rhythmites may represent annual

59 deposits.

\section{$60 \quad$ 2. Geologic Setting}

61 The Huronian Supergroup is a sedimentary-dominated succession that unconformably overlies

62 Archean rocks of the Superior Province north of Lake Huron in Ontario, Canada (Fig. 1). The

63 succession forms an approximately $325 \mathrm{~km}$ long belt that extends from Noranda, Quebec in the

64 northeast to the Sault Ste. Marie area in the west (Willingham et al., 1985). The Huronian

65 Supergroup is up to $12 \mathrm{~km}$ thick at its southern boundary where it underlies Paleozoic rocks of

66 the Michigan Basin (Young et al., 2001), and thins toward the north and west of the Southern

67 Province. The southeastern boundary of the Huronian Supergroup is characterized by the

68 Grenville Front, the remnants of a mountain building event that terminated at ca. 1.0 Ga (Moore

69 and Thompson, 1980). Rocks in the Bruce Mines-Elliot Lake area have been metamorphosed to

70 greenschist grade (Lindsey, 1969), but the prefix "meta" to describe the rock types is herein

71 omitted for simplicity. Tectonic deformation in the area between Sault Ste. Marie and Elliot Lake

72 ranges from low to moderate, and is characterized by upright, open folds with gently plunging

73 hinges (Bennett, 2006). Tectonic structures are poorly developed, and the beds in the study area 
74 dip between 4 and 30 degrees. It is therefore unlikely that rhythmite thicknesses have been 75 greatly modified.

76 The maximum age of the Huronian Supergroup is $2450+25 /-10 \mathrm{Ma}$, based on U-Pb zircon

77 analysis of the Copper Cliff Formation (Fig. 2; Krogh et al., 1984). The minimum age of the

78 Huronian Supergroup was determined to be 2217.0 $\pm 6.0 \mathrm{Ma}$ based on $\mathrm{U}-\mathrm{Pb}$ analysis of primary

79 baddeleyite from the Nipissing gabbro dikes that intrude the succession (Corfu and Andrews,

80 1986). Tang and Chen (2013) suggested that the duration of the Huronian glaciation events could

81 be constrained to 2.29-2.25 Ga, given their similarity to diamictite deposits in the Turee Creek

82 Group, Hammersley Basin, Western Australia; Makganyene Formation, Griqualand West Basin,

83 South Africa; Boshoek Formation and Duitschland Formation, Transvaal Basin, South Africa;

84 Sariolian Group, Karelian Supergroup, Eastern Baltic Shield, Russia; Chocolay Group,

85 Marquette Range Supergroup, Michigan/Wisconsin USA; and Snowy Pass Supergroup,

86 Wyoming, USA. Rasmussen et al. (2013) report a ca. 2.31 Ga U-Pb age from a purported tuff in

87 the Gordon Lake Formation, upper Huronian Supergroup, suggesting that most of the Huronian

88 formations are older than $2.31 \mathrm{Ga}$. The lower Huronian units (pre-Gowganda Formation) are

89 interpreted to have been deposited in transtensional to extensional (synrift) basins whereas the

90 upper Huronian Supergroup represents passive margin deposits (Young and Nesbitt, 1985;

91 Mustard and Donaldson, 1987; Holm et al., 2005; Eyles, 2008; Young, 2013).

92 The Hough Lake, Quirke Lake and Cobalt groups represent tripartite cycles, with each

93 containing glacial diamictite (poorly sorted, matrix-supported conglomerate) at their bases,

94 followed up-section by thinly laminated siltstone and claystone that are, in turn, overlain by 
95 arenaceous sandstone (Young et al., 2001). This complex period of glaciation has been identified

96 in the literature as the 'Huronian Glacial Event'. Striations and grooves on rock surfaces

97 underlying the diamictite, striated and faceted clasts within the diamictite, and the presence of

98 lonestones/dropstones in the fine-grained laminated deposits all support a glacial interpretation

99 for the basal units of the middle three Huronian groups (Lindsey, 1969; Young, 1970). The

100 argillites (meta-mudstones) and claystone/siltstone rhythmites that dominate the middle sections

101 of each formation have been interpreted as post-glacial deltaic deposits (Lindsey, 1969; Young et

102 al., 2001). The third stage of each glacial cycle is represented by cross-bedded, medium- to

103 coarse-grained sandstones interpreted as having been deposited in shallow marine, fluvial-deltaic

104 or fluvial environments (Palonen, 1973; Long, 1978; Young et al., 2001).

105 Interbedded siltstones and claystones that characterize the upper part of the Gowganda

106 Formation are inferred to represent a prodeltaic succession that was deposited as a continental ice

107 sheet retreated (Rainbird, 1985; Young et al., 2001; Long, 2009). The present study focuses on

108 the rhythmic deposits of the Gowganda Formation in the Bruce Mines/Elliot Lake area. One of

109 the outcrops, referred to as Outcrop A (the Wharncliffe argillite of Hughes et al., 2003), is

110 located adjacent to Highway 129, approximately $25 \mathrm{~km}$ north of Thessalon and $4 \mathrm{~km}$ north of

111 Wharncliffe, Ontario (Fig. 3). A second outcrop, Outcrop B, is located approximately $4 \mathrm{~km}$ east

112 of Outcrop A on County Road 554. A sedimentological analysis of the lithofacies in the study

113 area was conducted by Howe (2015) and is presented in Table 1.

\section{3. Evaluating Rhythmic Deposits using Cyclostratigraphy}


115 Cyclic stratigraphic processes such as sedimentation can be described and interpreted as periodic

116 oscillations. A periodic oscillation is mathematically described using a simple sinusoidal curve

117 consisting of a fixed amplitude, frequency and phase. Geological oscillations describing cyclic

118 stratigraphy are more complex in shape, and can be represented as a sum of multiple oscillations

119 with particular frequencies. Multiple frequencies comprise a spectrum, and the analysis of a

120 spectrum is called spectral analysis (Weedon, 2003). Where stratigraphic thicknesses are

121 sequentially measured at constant intervals, based on observable parameters such as recognizable

122 couplets, a cyclostratigraphic series of thickness vs cycle number analogous to a time series can

123 be formed, if three conditions are met: (1) environmental conditions are presumed consistent

124 throughout deposition of the facies, (2) the thickness of any individual bed results from the

125 influence of a single environmental variable, and (3) there is a relationship between the thickness

126 of any individual bed, and time (Weedon, 2003). In tidal or glacial depositional environments

127 where discrete sedimentation occurs, variations in bed thickness represent a modification of the

128 environment over time. The cyclostratigraphic series can be used to calculate cyclostratigraphic

129 spectra using well known methods of time series analysis. Care must be taken not to identify the

130 original data series with specific units of time, and the horizontal axes are always referred to

131 herein as "couplets". Similarly the resulting spectra will quantify the distribution of underlying

132 periodicities in terms of couplets per cycle. For the purpose of spectral analysis, it is assumed

133 that the stratigraphic record is composed of regular components (the signal) and irregular

134 components (the noise). The signal represents a periodic oscillation in some variable whereas the 135 noise represents an irregular oscillation (Weedon, 2003). 
136 Many studies have used spectral analysis to evaluate rhythmic deposits for periodicities that may

137 reflect the process of deposition (e.g. Williams 1985; Williams 1989; Godsey et al. 1999;

138 Rittenour et al., 2000; Hughes et al., 2003; Breckenridge, 2007; Andrews et al. 2010). Rhythmite

139 sequences in the Gowganda Formation have previously been considered as potential glacial

140 varves (Lindsey, 1969; Hughes et al., 2003), and therefore may represent some of the oldest

141 deglaciation deposits on Earth. However, tidal rhythmites (Williams, 1981; Williams, 1985;

142 Williams 1989) and turbidites (de Alvarenga and Trompette, 1992; Martins-Neto et al. 2001) in

143 the Proterozoic rock record can also present facies that are strikingly similar to varves. Thus, one

144 of the challenges facing the study of Paleoproterozoic rhythmites is that annual control may be

145 inferred, but not conclusively established, due to a lack of biogenic markers in the Precambrian 146 rock record.

\section{4. Methods}

148 The rhythmite units in Outcrop A and Outcrop B (Fig. 4) are morphologically similar, and are up

149 to 15 and $7 \mathrm{~m}$ thick, respectively. Selected rhythmite sections were measured at each outcrop

150 with a tape measure for the purpose of spectral analysis. Outcrop A and Outcrop B emerge from

151 the local soil on an angle, increasing in exposure height from north to south, and thus they were

152 measured in a stair-case fashion, with the bottom of each section being horizontally continuous

153 with the top of the previous section. Each couplet was measured from the base of a siltstone bed,

154 which generally had higher relief, to the top of the overlying claystone bed. 
155 The rhythmites at Outcrop A were separated into a lower and upper record by a $109 \mathrm{~cm}$ thick bed 156 that resembles a slump deposit. Therefore, the two records comprise sequential, but

157 discontinuous data sets. The lower record had a total thickness of $180 \mathrm{~cm}$, and was composed of 158 couplets ranged from $1-18 \mathrm{~mm}$ thick, with an average thickness of about $7 \pm 3 \mathrm{~mm}$ (reported as 159 standard deviation (SD) here and elsewhere; Fig. 5). The rhythmite measurements in the lower 160 record of Outcrop A do not display a trend of either increasing or decreasing thickness. The 161 upper record of Outcrop A contained a total thickness of $5 \mathrm{~m}$. The average couplet thickness for 162 the upper record of Outcrop A was $\sim 9 \pm 5 \mathrm{~mm}$, with couplet thickness measuring 1 - $32 \mathrm{~mm}$ (Fig.

163 5). The data from the upper record of Outcrop A shows a general increase in rhythmite thickness 164 up-section, which indicates an increasing sedimentation rate that may have been a result of 165 increased glacial melting under a warming environment (Ridge et al., 2012).

166 Two records were also measured at Outcrop B. The lower and upper records of Outcrop B are 167 separated by $80 \mathrm{~cm}$ of rhythmites that were too fractured to measure, and thus both records of 168 Outcrop B comprise sequential, yet discontinuous data sets. The lower record contained a total 169 thickness of $300 \mathrm{~cm}$. The couplets ranged in thickness from $3-31 \mathrm{~mm}$, with an average of $\sim 13 \pm 5$ $170 \mathrm{~mm}$ (Fig. 6). The upper record of Outcrop B measured a total thickness of $150 \mathrm{~cm}$, with couplets 171 ranging in thickness from 5 - $28 \mathrm{~mm}$ (average $=\sim 12 \pm 4 \mathrm{~mm}$; Fig.6). The thickness measurements

172 from both the lower and upper records of Outcrop B do not indicate an overall trend of

173 increasing or decreasing thickness, which may indicate a period of steady sedimentation or

174 reflect data sets that are too small to indicate an overall trend. Although the rhythmites of 
175 Outcrop A and Outcrop B are morphologically similar, it is not known whether they represent 176 the same, different, or overlapping depositional events.

177 Periodic cycles are often not visually apparent in raw data sets, and thus a spectral analysis of a 178 raw data set can be employed to identify periodicities. Spectral analysis of the rhythmite 179 measurements was conducted using the multitaper method ("MTM") as included in the MTM 180 Toolkit of Mann and Lees (1996). The MTM is a non-parametric method that employs the 181 discrete Fourier transform, and uses the average of multiple independent trials to estimate power 182 spectra (Thomson, 1982). In a climate time series, the MTM can be used to separate climatic 183 signals from the background noise in which they exist (Mann and Lees, 1996). Mann and Lees 184 (1996) describe the background noise in climate systems as "red noise", which is defined to be 185 composed of white noise and an enhanced, low-frequency, slow-response climate signal such as 186 that induced by the thermal inertia of the oceans. Red noise may comprise a significant 187 proportion of the time series, leading to a low signal-to-noise ratio. The MTM Toolkit of Mann 188 and Lees (1996) uses a first-order autoregressive (AR(1)) process to model the noise level, and 189 fits this model to the data in order to estimate the noise. The AR(1) process expresses each 190 sample in a time series as a linear combination of the previous sample and a white noise 191 contribution. By applying the AR(1) process to white noise, the lower frequencies are naturally 192 enhanced, leading to a red noise spectrum. The MTM combined with the red noise model allows 193 for improved noise identification, which leads to enhanced statistical significance of identified 194 signals. In this study, the datasets are sufficiently small to allow for the use of 3 tapers (where the 
195 number of tapers used is $K=2 p-1$ ) and a time-frequency bandwidth $p$ of 2 ; these parameters 196 were used throughout the study.

\section{5. Results}

198 Couplet measurement data provided by Gary Hughes (used in the Hughes et al. 2003 study) were 199 processed using the MTM Toolkit (Fig. 7). Spectral analysis results from the measurements at 200 Outcrops A and B are provided in Figures 8 and 9. In these figures, "harmonic peaks" represent 201 periodic signals that correspond to singular peaks in the power spectrum estimated by the MTM;

202 the "reshaped" spectrum is calculated using a modified version of the reshaping process of

203 Thomson (1982), the AR(1) red noise spectrum is estimated from the median-smoothed spectrum 204 to provide a robust model for the noise background, and the "median" line depicts the red-noise 205 fit to the median-smoothed spectrum (calculated by replacing each frequency point in the 206 reshaped spectrum with its median value). Three confidence levels are used to evaluate the 207 distribution of the frequency as depicted by the reshaped spectrum, relative to background noise: $20890 \%, 95 \%$ and $99 \%$ (Figs. 7-9).

209 The MTM results produced from the Hughes et al. (2003) data (Fig. 7) are similar to the 210 published results in that paper. In the MTM results from the lower record of Outcrop A (Fig. 8)

211 quasi-periodic cycles of 4.4 and 9.2 couplets were detected with a $90 \%$ degree of certainty.

212 Quasi-periodic cycles of 2.2 and 6.6 couplets were detected with a 95\% degree of certainty, and 213 a quasi-periodic cycle of 2.9 couplets was detected with a $99 \%$ degree of certainty. In the MTM 214 results from the upper record of Outcrop A (Fig. 8), a number of quasi-periodic cycles in the 
215 range of 2.3 to 4.4 couplets were found, in addition to quasi-periodic cycles of 4.9 and 8.8

216 couplets, all having a 90\% degree of certainty. A quasi-periodic cycle of 22.8 couplets, having a

$21795 \%$ degree of certainty, was also identified. Quasi-periodic cycles of 56.9 and 31.0 couplets

218 (99\% certainty) were also evident, in addition to a harmonic cycle of 2.4 couplets.

219 The MTM results from the lower record of Outcrop B (Fig. 9) show a number of quasi-periodic 220 cycles in the range of 2.3 to 4.4 couplets, and a quasi-periodic cycle of 30.1 couplets, all with a $22190 \%$ degree of certainty. A harmonic cycle of 2.8 couplets was also observed. The results from

222 the upper record of Outcrop B (Fig.9) indicate a quasi-periodic cycle of 6.9 couplets having a $22399 \%$ degree of certainty, and minor quasi-periodic cycles in the range of 2.9 to 3.4 couplets $(90 \%$ $224-95 \%$ degree of certainty).

\section{6. Discussion}

227 Varves are difficult to conclusively identify in the Precambrian rock record because of the lack

228 of time indicators, such as summer deposition of pollen, that allow for interpretations of annual

229 control. The potential result is misinterpretation of tidal-induced rhythmites as varves.

230 Rhythmically laminated sediments deposited from tidal activity are called tidal rhythmites or

231 tidalites (Klein, 1971; Chan et al., 1994). Tidal rhythmites are composed of alternating

232 sandstone/siltstone and claystone laminations that reflect the flood and ebb stages of diurnal or

233 semidiurnal tides. Traction currents operating during the flood and ebb stages of a tidal cycle

234 deposit coarse-grained (silty) sediment, whereas fine-grained (muddy) material is deposited 
235 during the slackwater period when the flow direction alternates (Klein, 1971). Although tidal

236 rhythmites may resemble varves in the rock record, changes in the lunar and solar cycles

237 influence the strength of tidal flow, resulting in periodic variations in bed thickness (Williams,

238 1989). Maximum rhythmite thickness occurs at the peak of the spring tide, with rhythmite

239 thickness decreasing as the tide cycle progresses to the neap tide (Archer et al., 1990). Typically,

240 the planar-laminated silty layers are much thicker than the thin clay drapes that overlie them

241 (Archer et al., 1995). In Precambrian tidal settings, the lunar month has been estimated to contain

242 between 30.5 days (Williams 1989; Williams 1991) and 32 days (Mazumder, 2004).

243 Precambrian varves can be distinguished from tidalites based on morphology (e.g. Hughes et al.

244 2003; Andrews et al. 2010), sedimentology, and/or spectral analysis results that preclude tidalite-

245 like periodicities. In this study, the rhythmites typically have claystone layers that are thicker

246 than the siltstone layers (Table 1), and the opposite would be expected if the rhythmites were

247 tidalites. In addition, a pronounced cycle of rhythmite thickening and thinning typical of tidalites

248 (Archer et al., 1990), was not observed (Fig. 4). The rocks studied contain no sedimentary

249 structures consistent with a tidally-influenced setting, such as mud cracks, reactivation surfaces,

250 or herringbone cross stratification. Morphological, sedimentological and spectral analysis

251 observations, therefore, strongly suggest that the rhythmites are not tidalites. In addition, the

252 sedimentation rate in this study ranges from 1-32 $\mathrm{mm}$ per rhythmic cycle, which compares

253 favorably with typical Holocene varves that measure from $1 \mathrm{~mm}$ to more than $50 \mathrm{~mm}$ thick

254 (Godsey, 1999; Rittenour, 2000; Breckenridge, 2007). Given the available evidence, combined

255 with the presence of dropstones in some of the rhythmite layers, we hypothesize that the 
256 rhythmites could represent annual depositional cycles. In the following section we examine the

257 implications of such a hypothesis, and we present evidence that the resulting periodicities are 258 consistent with periodicities seen in modern climate systems.

\subsection{Consistent Periodicities}

260 If the deposits of Outcrop A are considered to represent annual rhythmites and a similar

261 interpretation is extended to Outcrop B, then the results of this study can be compared to those of

262 Hughes et al. (2003) (Table 2), and to those determined from investigations of Holocene and

263 Pleistocene varves. With one exception, the MTM Toolkit identified peaks in the Hughes data

264 similar to those published in Hughes et al. (2003), thereby validating the method used. A cluster

265 of periodicities within the range of $2.2-2.9$ couplets per cycle was determined from all four of

266 the rhythmite records in this study, as well as from the data of Hughes et al. (2003), and from

267 studies of varves in Lake Superior (Breckenridge, 2007), glacial Lake Hitchcock (Rittenour et

268 al., 2000) and Lake Huron (Godsey et al., 1999) (Table 3). If the couplets do correspond to

269 annual deposition beds, then cycles within this range $(2.2-2.9$ years per cycle) are reminiscent

270 of the modern day quasi-biennial oscillation (QBO), which is a periodic change in stratospheric

271 equatorial wind directions that cyclically varies with a period of 22 to 34 months (Baldwin et al.,

272 2001). The QBO impacts the stratospheric polar vortex, which in turn influences weather

273 patterns on the surface of the Earth. Godsey et al. (1999) also attributed periodicities within the

274 range of 2 - 3 years to the Southern Oscillation Index, which is a measure of air pressure

275 fluctuations resulting from ocean temperature differences between the western and eastern 276 tropical Pacific. 
277 A number of low periodicity events within the range of $3.0-6.9$ couplets per cycle were also

278 determined from the four rhythmite records in this study. Godsey et al. (1999) and Rittenour et

279 al. (2000) attribute periodicities of three to seven years to climatic fluctuations associated with

280 ENSO, the El Niño - Southern Oscillation. Hughes et al. (2003) and Breckenridge (2007)

281 attribute periodicities of three to six years to ENSO, and periodicities of six to seven years to

282 NAO, the North Atlantic Oscillation. If the hypothesis of annual deposition is accepted, then it

283 is apparent that these periodicities are also present in the Gowganda Formation. The sediment

284 record therefore hints that climate systems similar to QBO and ENSO may have been operational

285 during the Paleoproterozoic, and supports the hypothesis that these ancient rhythmic couplets

286 were deposited on an annual basis.

\subsection{Inconsistent Periodicities}

288 Table 2 indicates that some periodicities do not appear in all records, indicating that they may 289 not preserve climatic cycles, and they are thus, not considered here. There are a number of 290 reasons why certain periodicities may be observed in only one or two records. These

291 inconsistencies may arise from variations in depositional environments. The couplets at Outcrop 292 A are composed of claystone and siltstone, whereas the couplets at Outcrop B are composed of 293 fine- and coarse-grained siltstone. This variance may be attributed to different locations within 294 one deltaic environment, different locations in separate deltaic or basinal environments, temporal 295 variations in deposition, or a combination of these factors. In addition, if glacial melting ceases 296 completely for an extended time period, there is no accounting for the "missing data" in the 297 spectral analysis model. 
298 The depositional environment for the upper Gowganda Formation in the study area is

299 dynamically complex, with sedimentation that may have been influenced by both delta

300 progradation and glacial recession (Howe, 2015). Locally, delta progradation results in

301 increasingly thicker beds (Reineck and Singh, 1980), whereas glacial recession results in lower

302 sedimentation rates (Fleisher et al., 2003). Variances in rhythmite thickness can therefore result

303 independent of external forcing. Ridge et al. (2012) also noted that prodeltaic varves may be

304 difficult to correlate on a regional basis because of the influence of local processes.

305 Multiple depositional processes may also be contained within the annual boundaries delineating

306 a single varve. In a study of Nicolay Lake, located on Cornwall Island in the Canadian High

307 Arctic, Hambley and Lamoureux (2006) identified three subannual depositional layers found

308 within the annual parameters that define a varve: (1) a basal layer deposited by sedimentation

309 resulting from nival melt in the spring; (2) a layer resulting from hydrological events induced by

310 precipitation, and (3) a layer resulting from sporadic mass wasting events such as turbidites or

311 slumps. By comparing local weather station records with nival melt rhythmite thicknesses,

312 Hambley and Lamoureux (2006) found a strong correlation between nival melt sedimentation

313 and cumulative seasonal melt degree days. The combined measured thickness variations in

314 meteoric-induced hydrological events and mass wasting events however, were demonstrated to

315 be randomly variable and not associated with cumulative melt degree-days in a season, which

316 may partially account for the inconclusive spectral analysis results of their study.

\section{6.3. Robustness of the model}


318 Spectral analysis investigations often invoke the use of two models to demonstrate that results

319 are consistent (e.g. Andrews et al., 2010; Ojala et al., 2015). In the present study, the model that

320 was chosen (Mann and Lees, 1996) was designed for, and has been demonstrated to work with,

321 natural phenomena such as rhythmic laminations and tree-ring growth. Notwithstanding the

322 designed intention of the model, the output may contain false-positive results (Mann and Lees,

323 1996). This study however, is predominantly concerned with relative comparisons among similar

324 deposits, and therefore a single model was deemed sufficient. Moreover, the MTM results were

325 shown to be consistent with the results of Hughes et al. (2003), who used the Maximum Entropy

326 Method with the same data. Another issue facing spectral analysis modelling is that of

327 persistence, which relates to zones (subsets) of anomalous data that may influence the results of

328 the entire dataset. In geological terms, this may be represented by a period of extended warmth

329 leading to rhythmites that are generally thicker than those that are predominant in the record.

330 The present study also utilized small datasets, which (under the assumption of annual deposition)

331 limited the output potential to decadal-scale results. Although this allowed for the possibility of

332 finding short-term solar cycles related to sunspot activity (11 yr and $22 \mathrm{yr}$ periodicities), none

333 were consistently identified. This result is consistent with those of Zhao and Feng (2015), who

334 found no connection between short-term solar cycles (11 and $22 \mathrm{yr}$ periodicities) and local

335 temperatures in modern Antarctica.

\section{Conclusions}

337 Rhythmic couplets of the upper Gowganda Formation preserve a high-resolution record of 338 climatic variance during the Paleoproterozoic. MTM spectral analysis using time-series from 
Page 18 of 50

339 four rhythmic couplet records measured in the field at two outcrop locations consistently

340 revealed periodicities in the thickness of the rhythmites with periods of ca. 3 couplets per cycle.

341 Modern annual climatic cycles such as the QBO and the ENSO also display periodicities of 3

342 years. Longer term periodicities of 3.0-14.3 couplets, 22.8 couplets, 30.1-31.0 couplets and 56.9

343 couplets were also preserved, but none of these results were represented in all four rhythmite

344 records. The lack of consistency among all four rhythmite records for periodicities greater than 3

345 couplets may be the result of variations in the varve formation process or the depositional

346 environment, gaps in the varve chronology, or errors attributed to the model. If climatic cycles

347 similar to the QBO and the ENSO were operational during the Paleoproterozoic, the rhythmic

348 couplets probably represent annual deposits (i.e. varves), and thus preserve a detailed record of

349 Paleoproterozoic climate.

\section{Acknowledgements}

353 The authors gratefully acknowledge the provision of the raw data from Hughes et al. (2003) by

354 G. Hughes., as well as discussions held with Dr. K. Tiampo who suggested the use of the MTM

355 toolkit and provided access to Linux-based computers. This work was financially supported by

356 an Academic Development Fund Major Grant provided to P. Corcoran by the University of

357 Western Ontario. 


\section{References}

359 Agterberg, F.P. and Banerjee, I., 1969. Stochastic model for the deposition of varves in glacial 360 Lake Barlow-Ojibway, Ontario, Canada. Can. J. Earth Sci. 6, 625-652.

361 Andrews, S.D., Trewin, N.H., Hartley, A.J., Weedon, G.P., 2010. Solar variance recorded in

362 lacustrine deposits from the Devonian and Proterozoic of Scotland. J. Geol. Soc. 167, 847-856.

363 Antevs, E., 1925. Retreat of the last ice sheet in eastern Canada. Geol. Surv. Can. Mem. 146, 364 142pp.

365 Archer, A.W., Kvale, E.P., Johnson, H.R., Williams, G., 1990. Discussion on Late Precambrian 366 tidal rhythmites in South Australia and the history of the Earth's rotation-reply. J. Geol. Soc. $367147,401-407$.

368 Archer, A.W., Kuecher, G.J., Kvale, E.P., 1995. The role of tidal-velocity asymmetries in the 369 deposition of silty tidal rhythmites (Carboniferous, Eastern Interior Coal Basin, U.S.A.). J. 370 Sediment. Res. 65, 408-416.

371 Baldwin, M.P., Gray, L.J., Dunkerton, T.J., Hamilton, K., Haynes, P.H., Randel, W.J., Holton, 372 J.R., Alexander, M.J., Hirota, I., Horinouchi, T., Jones, D.B.A., Kinnersley, J.S., Marquardt, C., 373 Sato, K., Takahashi, M., 2001. The quasi-biennial oscillation. Rev. Geophys. 39, 179-229.

374 Bennett, G., 2006. The Huronian Supergroup Between Sault Ste. Marie and Elliot Lake. Institute 375 on Lake Superior Geology, 74pp. 
Page 20 of 50

376 Bramlette, M.N., 1946. The Monterey Formation of California and the origin of its siliceous

377 rocks. U.S. Geol. Surv. Prof. Pap. 212, 57pp.

378 Breckenridge, A., 2007. The Lake Superior varve stratigraphy and implications for eastern Lake

379 Agassiz outflow from 10,700 to 8900 cal ybp $\left(9.5-8.0{ }^{14} \mathrm{C}\right.$ ka). Palaeogeogr. Palaeoclimatol.

380 Palaeoecol. 246, 45-61.

381 Chan, M.A., Kvale, E.P., Archer, A.W., Sonett, C.P., 1994. Oldest direct evidence of lunar-solar

382 tidal forcing encoded in sedimentary rhythmites, Proterozoic Big Cottonwood Formation, central

383 Utah. Geology 22, 791-794.

384 Corfu, F., Andrews, A., 1986. A U-Pb age for mineralized Nipissing diabase, Gowganda,

385 Ontario. Can. J. Earth Sci. 23, 107-109.

386 de Alvarenga, C.J., Trompette, R., 1992. Glacially influenced sedimentation in the later

387 Proterozoic of the Paraguay Belt (Mato Grosso, Brazil). Palaeogeogr. Palaeoclimatol.

388 Palaeoecol. 92, 85-105.

389 De Geer, G., 1912. Geochronology of the last 12,000 years. In: 11th International Geological

390 Congress (1910), Stockholm, Sweden, vol. 1, pp. 241-253.

391 Delaney, C., 2005. Seasonal controls on deposition of Late Devensian glaciolacustrine

392 sediments, central Ireland. In: Hambrey, M.J., Christofferson, P., Glasser, N.F., Hubbard, B.

393 (Eds.), Glacial Sedimentary Processes and Products, Int. Assoc. Sedimentologists Spec. Pub. 39, 394 149-163. 
Page 21 of 50

395 Eyles, N., 2008. Glacio-epochs and the supercontinent cycle after 3.0 Ga: Tectonic boundary 396 conditions for glaciation. Palaeogeogr. Palaeoclimatol. Palaeoecol. 258, 89-129.

397 Fleisher, P.J., Bailey, P.K., Cadwell, D.H., 2003. A decade of sedimentation in ice-contact, 398 proglacial lakes, Bering Glacier, AK. Sediment. Geology 160, 309-324.

399 Freeman, E. B., 1978. Geological Highway Map, Southern Ontario; Ont. Geol. Surv., Map 2418

400 Godsey, H.S., Moore, T.C., Rea, D.K., Shane, L.C.K., 1999. Post-Younger Dryas seasonality in 401 the North American midcontinent region as recorded in Lake Huron varved sediments. Can. J. 402 Earth Sci. 36, 533-547.

403 Hambley, G.W., Lamoureux, S.F., 2006. Recent summer climate recorded in complex varved 404 sediments, Nicolay Lake, Cornwall Island, Nunavut, Canada. J. Paleolimnol. 35, 629-640.

405 Holm, D.K., Van Schmus, W.R., MacNeill, L.C., Boerboom, T.J., Schweitzer, D., Schneider, D., 406 2005. U-Pb zircon geochronology of Paleoproterozoic plutons from the northern midcontinent, 407 USA: Evidence for subduction flip and continued convergence after geon 18 Penokean 408 orogenesis. Geol. Soc. Am. Bull. 117, 259-275.

409 Howe, T.S., 2015. Investigating potential climatic cycles in glacially-influenced rhythmites of 410 the upper Gowganda Formation using geochemical, sedimentological and spectral analyses. 411 Master's Thesis, Western University. 
Page 22 of 50

412 Hughes, G.B., Giegengack, R., Kritikos, H.N., 2003. Modern spectral climate patterns in

413 rhythmically deposited argillites of the Gowganda Formation (Early Proterozoic), southern

414 Ontario, Canada. Ear. Plan. Sci. Lett. 207, 13-22.

415 Klein, G.D., 1971. A sedimentary model for determining paleotidal range. Geol. Soc. Am. Bull. $41682,2585-2592$.

417 Krogh, T., Davis, D., Corfu, F., 1984. Precise U-Pb zircon and baddeleyite ages for the Sudbury 418 area, in: Pye, E.G., Naldrett, A.J., Giblin, P.E. (Eds.), The Geology and Ore Deposits of the 419 Sudbury Structure, Ont. Geol. Surv., Spec., Vol. 1, pp. 431-446.

420 Lindsey, D.A., 1969. Glacial sedimentology of the Precambrian Gowganda Formation, Ontario, 421 Canada. Geol. Soc. Am. Bull. 80, 1685-1702.

422 Long, D.G., 1978. Depositional environments of a thick Proterozoic sandstone: the (Huronian) 423 Mississagi Formation of Ontario, Canada. Can. J. Earth Sci. 15, 190-206.

424 Long, D.G., 2004. The tectonostatigraphic evolution of the Huronian basement and the 425 subsequent basin fill: geological constraints on impact models of the Sudbury event. 426 Precambrian Res. 129, 203-223.

427 Long, D.G., 2009. The Huronian Supergroup, in: Rousell, D.H. and Brown, G.H. (Eds.), A Field 428 Guide to the Geology of Sudbury, Ontario, Ont. Geol. Surv., Open File Rep. 6243, pp. 14-30. 
Page 23 of 50

429 Mann, M.E., Lees, J.M., 1996. Robust estimation of background noise and signal detection in a 430 climatic time series. Clim. Change 33, 409-445.

431 Martins-Neto, M.A., Pedrosa-Soares, A.C., Lima, S.A.D.A., 2001. Tectono-sedimentary

432 evolution of sedimentary basins from Late Paleoproterozoic to Late Neoproterozoic in the Sao

433 Francisco craton and Araçua1 fold belt, eastern Brazil. Sediment. Geol. 141, 343-370.

434 Mazumder, R., 2004. Implications of lunar orbital periodicity from the Chaibasa tidal rhythmite 435 (India) of late Paleoproterozoic age. Geology 32, 841-844.

436 Moore Jr, J.M., Thompson, P.H., 1980. The Flinton Group: a late Precambrian metasedimentary

437 succession in the Grenville Province of eastern Ontario. Can. J. Earth Sci. 17, 1685-1707.

438 Mustard, P., Donaldson, J., 1987. Early Proterozoic ice-proximal glaciomarine deposition: the 439 lower Gowganda Formation at Cobalt, Ontario, Canada. Geol. Soc. Am. Bull. 98, 373-387.

440 Ojala, A.E.K., Francus, P., Zolitschka, B., Besonen, M., \& Lamoureux, S.F., 2012.

441 Characteristics of sedimentary varve chronologies-a review. Quat. Sci. Rev., 43, 45-60.

442 Palonen, P., 1973. Paleogeography of the Mississagi Formation and lower Huronian cyclicity, in:

443 Young, G.M. (Ed.), Huronian Stratigraphy and Sedimentation, Geol. Assoc. Canada Spec. Pap.

444 12, pp. 157-167. 
Page 24 of 50

445 Rainbird, R.H., 1985. Sedimentology and geochemistry of the Firstbrook Member of the

446 Gowganda Formation in the eastern Cobalt Basin, M.Sc. thesis, Carleton University, Ottawa,

447 Ont., Canada, 157 pp.

448 Rasmussen, B., Bekker, A. and Fletcher, I.R., 2013. Correlation of Paleoproterozoic glaciations

449 based on $\mathrm{U}-\mathrm{Pb}$ zircon ages for tuff beds in the Transvaal and Huronian Supergroups. Earth

$450 \quad$ Planet. Sci. Lett. 382, 173-180.

451 Reineck, H.E., Singh, I.B., 1972. Genesis of laminated sand and graded rhythmites in storm-sand

452 layers of shelf mud. Sedimentol. 18, 123-128.

453 Reineck, H.E., Singh, I.B., 1980. Depositional Sedimentary Environments: With Reference to

454 Terrigenous Clastics. Springer-Verlag, Berlin, 549pp.

455 Ridge, J.C., Balco, G., Bayless, R.L., Beck, C.C., Carter, L.B., Dean, J.L., Voytek, E.B., Wei,

456 J.H., 2012. The new North American Varve Chronology: A precise record of southeastern

457 Laurentide Ice Sheet deglaciation and climate, 18.2-12.5 kyr BP, and correlations with

458 Greenland ice core records. Am. J. Sci. 312, 685-722.

459 Rittenour, T.M., Brigham-Grette, J., Mann, M.E., 2000. El Niño-like climate teleconnections in

460 New England during the late Pleistocene. Science 288, 1039-1042.

461 Tang, H., Chen, Y., 2013. Global glaciations and atmospheric change at ca. 2.3 Ga. Geosci.

462 Front. 4, 583-596. 
Page 25 of 50

463 Thomson, D.J., 1982. Spectrum estimation and harmonic analysis. Proc IEEE 70: 1055-1096.

464 Weedon, G.W., 2003. Time-Series Analysis and Cyclostratigraphy: Examining stratigraphic

465 records of environmental cycles, Cambridge University Press, UK, 259pp.

466 Williams, G., 1981. Sunspot periods in the late Precambrian glacial climate and solar-planetary

467 relations. Nature 291, 624-628.

468 Williams, G., 1985. Solar affinity of sedimentary cycles in the late Precambrian Elatina

469 Formation. Australian J. Physics 38, 1027-1044.

470 Williams, G.E., 1989. Late Precambrian tidal rhythmites in South Australia and the history of the

471 Earth's rotation. J. Geol. Soc. 146, 97-111.

472 Williams, G.E., 1991. Upper Proterozoic tidal rhythmites, South Australia: sedimentary features,

473 deposition, and implications for the earth's paleorotation. In: Smith, D.G., Reinson, G.E., Zaitlin,

474 B.A., Rahmani, R.A. (Eds.), Clastic Tidal Sedimentology, Can. Soc. Pet. Geol. Mem. 16, 161-

$475 \quad 177$.

476 Williams, G.E., 2000. Geological constraints on the Precambrian history of Earth's rotation and

477 the Moon's orbit. Rev. Geophys. 38, 37-59.

478 Willingham, T.O., Nagy, B., Nagy, L.A., Krinsley, D.H., Mossman, D.J., 1985. Uranium-bearing

479 stratiform organic matter in paleoplacers of the lower Huronian Supergroup, Elliot Lake-Blind

480 River region, Canada. Can. J. Earth Sci. 22, 1930-1944. 
Page 26 of 50

481 Young, G.M., 1970. An extensive early Proterozoic glaciation in North America? Palaeogeogr.

482 Palaeoclimatol. Palaeoecol. 7, 85-101.

483 Young, G.M., 2013. Climatic catastrophes in Earth history: two great Proterozoic glacial

484 episodes. Geol. J. 48, 1-21.

485 Young, G.M., Nesbitt, H.W., 1985. The Gowganda Formation in the southern part of the

486 Huronian outcrop belt, Ontario, Canada: Stratigraphy, depositional environments and regional

487 tectonic significance. Precambrian Res. 29, 265-301.

488 Young, G.M., Long, D.G.F., Fedo, C.M., Nesbitt, H.W., 2001. Paleoproterozoic Huronian basin:

489 product of a Wilson cycle punctuated by glaciations and a meteorite impact. Sediment. Geol.

$490 \quad 141,233-254$.

491 Zhao, X.H., Feng, X.S., 2015. Correlation between solar activity and the local temperature of

492 Antarctica during the past 11,000 years. J. Atmos. Sol. Terr. Phys. 122, 26-33.

493 


\section{$494 \quad$ Figure Captions}

495 Figure 1: Distribution of the Huronian Supergroup in Ontario, Canada. The Huronian

496 Supergroup comprises the eastern section of the Southern Province, and is divided into three

497 regions: the Bruce Mines/Elliot Lake area, the Espanola/Whitefish Falls area and the Cobalt area.

498 The Flack Lake fault and the Murray fault zone (dashed lines) indicate contemporaneous down-

499 to-basin faulting. Map modified from Freeman (1978) and Young et al. (2001)

500 Figure 2: Generalized stratigraphic section of the Huronian Supergroup. Note the repeating

501 cycles of conglomerate overlain by siltstone or limestone, overlain by sandstone in each of the

502 Hough Lake, Quirke Lake and Cobalt groups. The informal Flack Lake Group serves to separate

503 the non-cyclical Gordon Lake and Bar River formations from the Cobalt Group (after Long,

504 2004).

505 Figure 3: Locations of studied outcrops in the Bruce Mines/Elliot Lake study area. Outcrop A

506 also represents the location of the Hughes et al. (2003) study.

507 Figure 4: Characteristics of the rhythmites studied. A: Photograph of an approximately $4 \mathrm{~m}$ thick

508 section of Outcrop A. B: Photograph of partial rhythmite sequence from Outcrop A, which

509 locally contains granule- to boulder-size dropstones. C: Rhythmites at Outcrop B. Student is

510 approximately $1.8 \mathrm{~m}$ tall. D: Photograph of partial rhythmite sequence at Outcrop B, which does

511 not contain dropstones. Distance between tape markings is $30 \mathrm{~cm}$. 
512 Figure 5: (Bottom) Thickness of the 229 couplets that compose the lower set of measurements 513 from Outcrop A. (Top) Thickness of the 585 couplets that compose the upper set of 514 measurements from Outcrop A.

515 Figure 6: (Bottom) Thickness of the 216 couplets that compose the lower set of measurements 516 from Outcrop B. (Top) Thickness of 119 couplets that compose the upper set of measurements 517 from Outcrop B.

518 Figure 7: Spectral analysis results using the method of Mann and Lees (1996) for the rhythmite 519 measurements of Hughes et al. (2003) with median, and 90\%, 95\% and 99\% confidence interval 520 bands. Quasi-periodic cycles with periods ranging from 2.3 to 13.3 couplets are shown. A 521 harmonic cycle of period 2.7 couplets is indicated by the open rectangle.

522 Figure 8: (Bottom) Spectral analysis results using the method of Mann and Lees (1996) for the 523 lower rhythmite measurements from Outcrop A with median, and 90\%, 95\% and 99\% 524 confidence interval bands. Quasi-periodic cycles with periods ranging from 2.2 to 9.2 couplets 525 are shown. (Top) Spectral analysis results using the method of Mann and Lees (1996) for the 526 upper rhythmite measurements from Outcrop A with median, and 90\%, 95\% and 99\% 527 confidence interval bands. Quasi-periodic cycles with periods ranging from 2.3 to 56.9 couplets 528 are shown. A harmonic cycle of about 2.5 couplets is indicated by an open rectangle.

529 Figure 9: (Bottom) Spectral analysis results using the method of Mann and Lees (1996) for the 530 lower rhythmite measurements from Outcrop B with median, and 90\%, 95\% and 99\%

531 confidence interval bands. Quasi-periodic cycles with periods ranging from 2.3 to 30.1 couplets 


\section{Page 29 of 50}

532 are shown. A harmonic cycle with a period of about 2.8 couplets is indicated by the open 533 rectangle. (Top) Spectral analysis results using the method of Mann and Lees (1996) for the

534 upper rhythmite measurements from Outcrop B with median, and 90\%, 95\% and 99\%

535 confidence interval bands. Quasi-periodic cycles with a period ranging from 2.9 to 6.9 couplets 536 are shown. 
Page 30 of 50

\section{$538 \quad$ Figures}

539 Figure 1
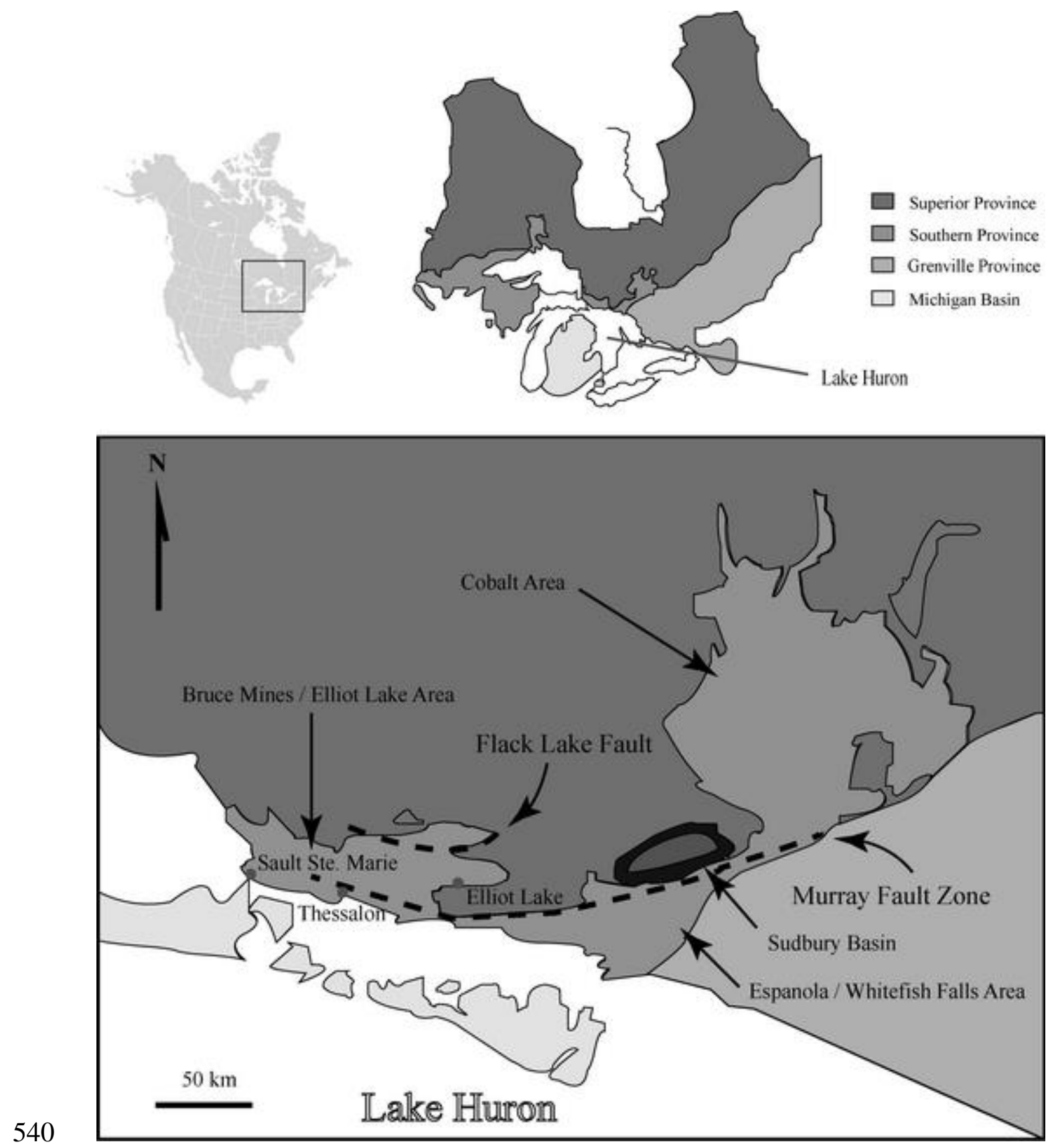
Page 31 of 50

542

Figure 2

\section{Huronian Supergroup}

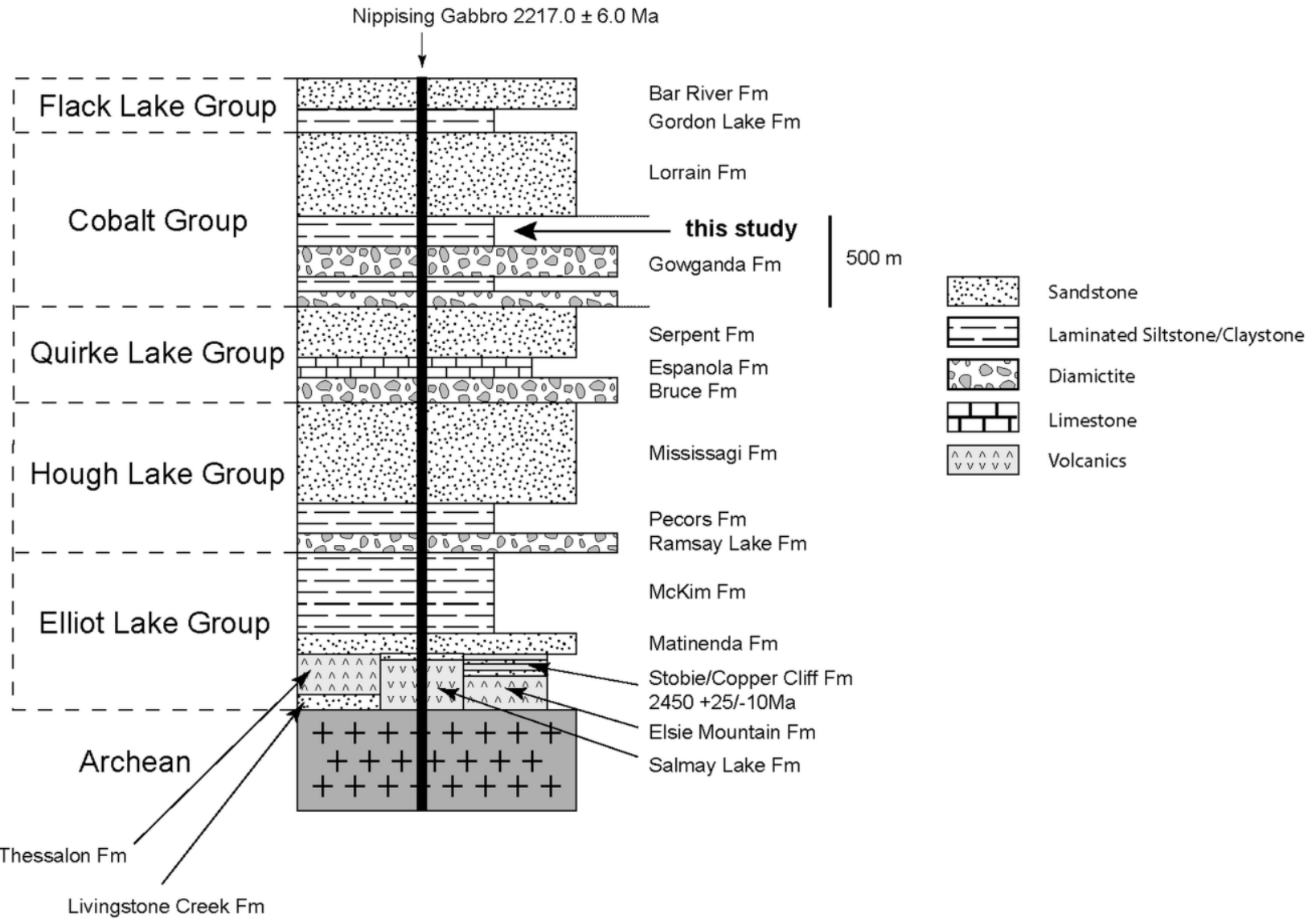


Page 32 of 50

$545 \quad$ Figure 3

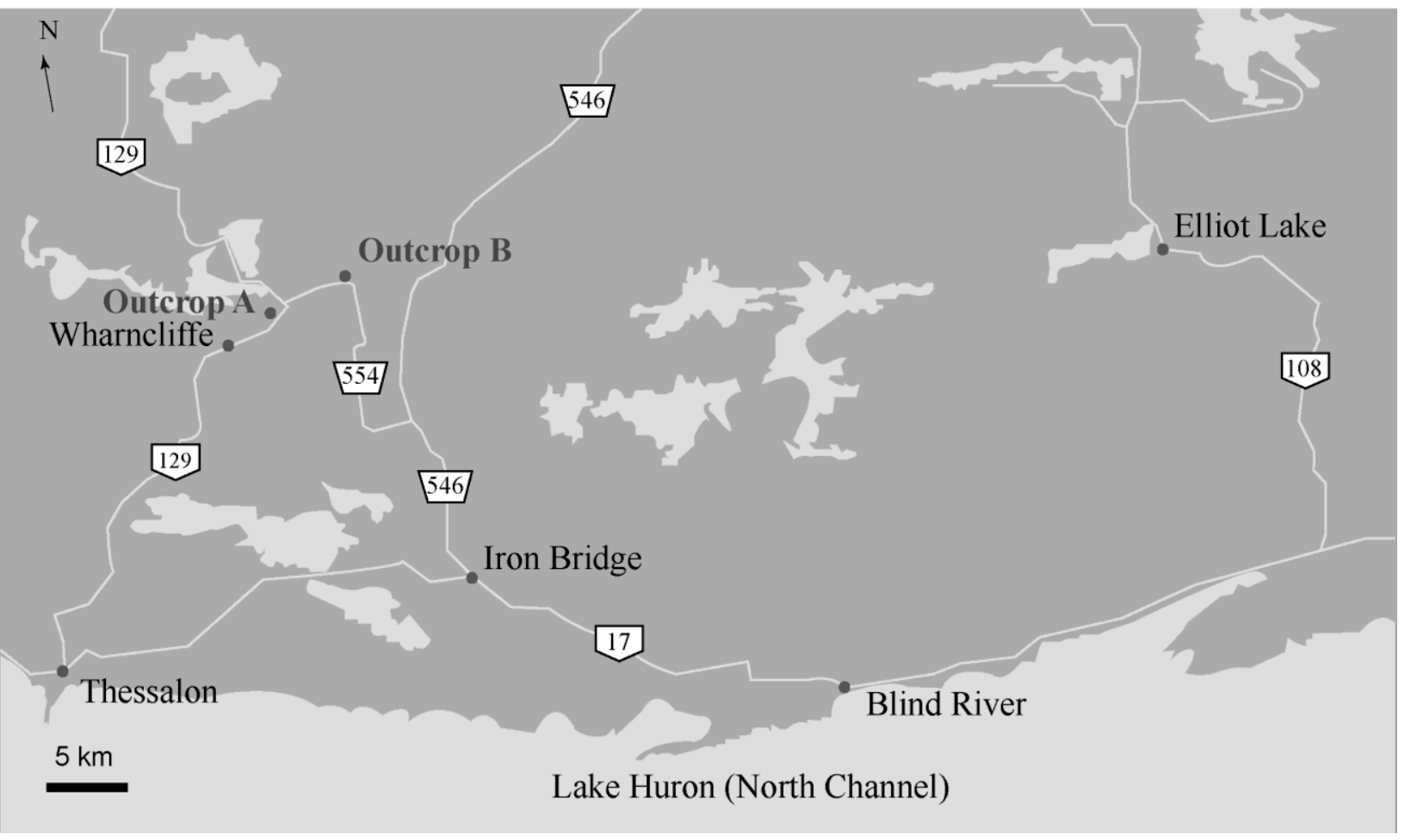


Page 33 of 50

$550 \quad$ Figure 4

551

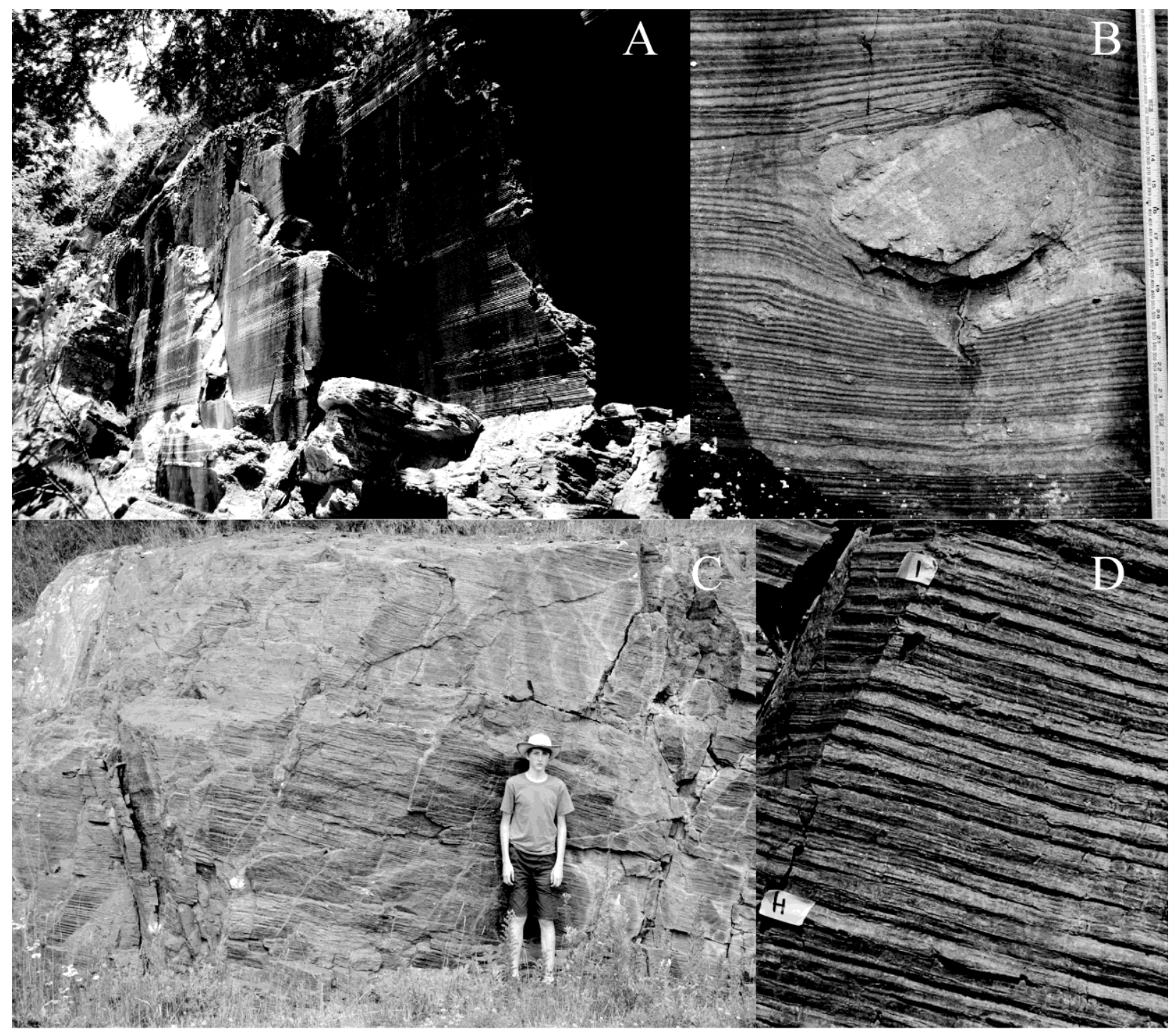


Page 34 of 50

554 Figure 5

Outcrop A Rhythmite Measurements (upper)

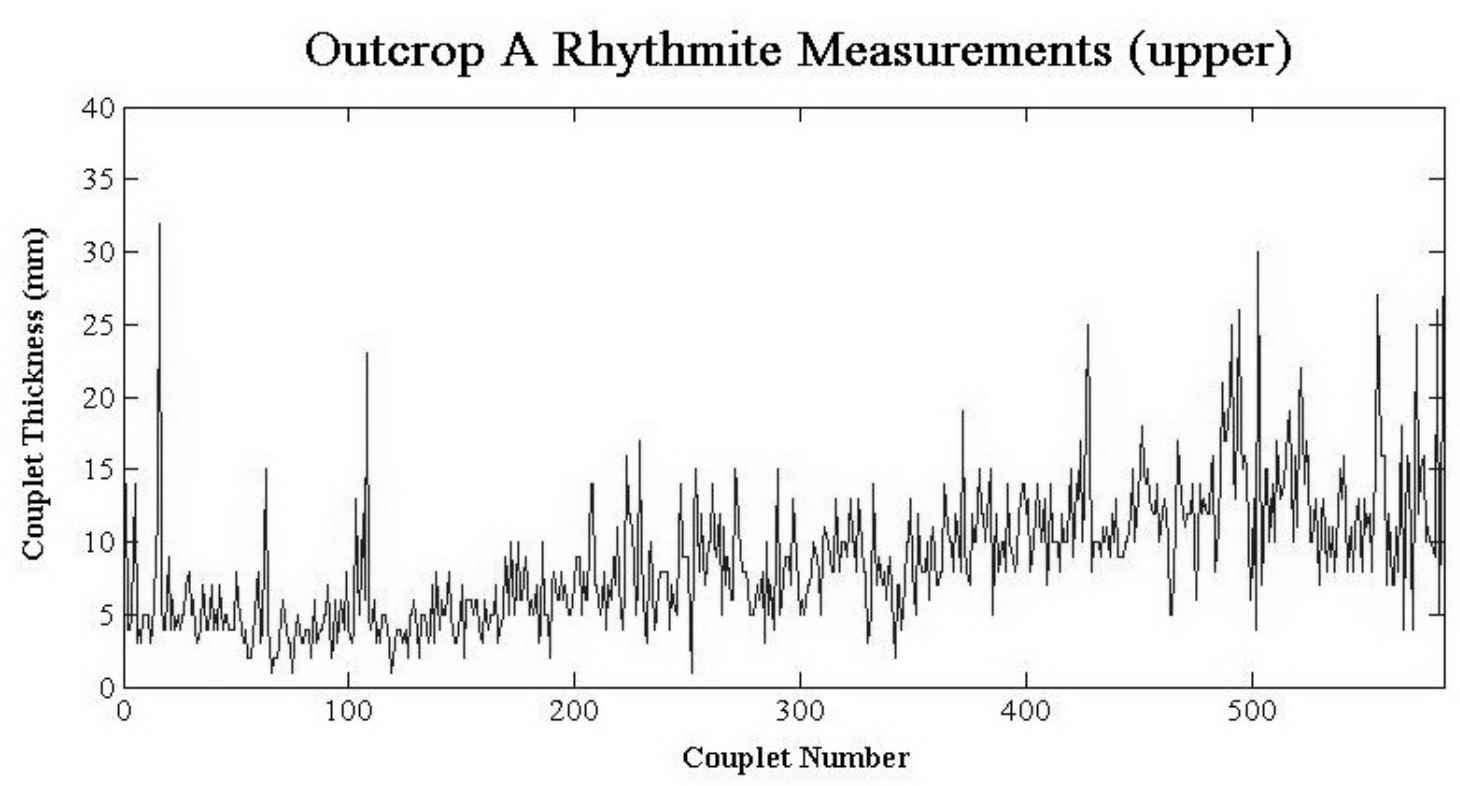

555

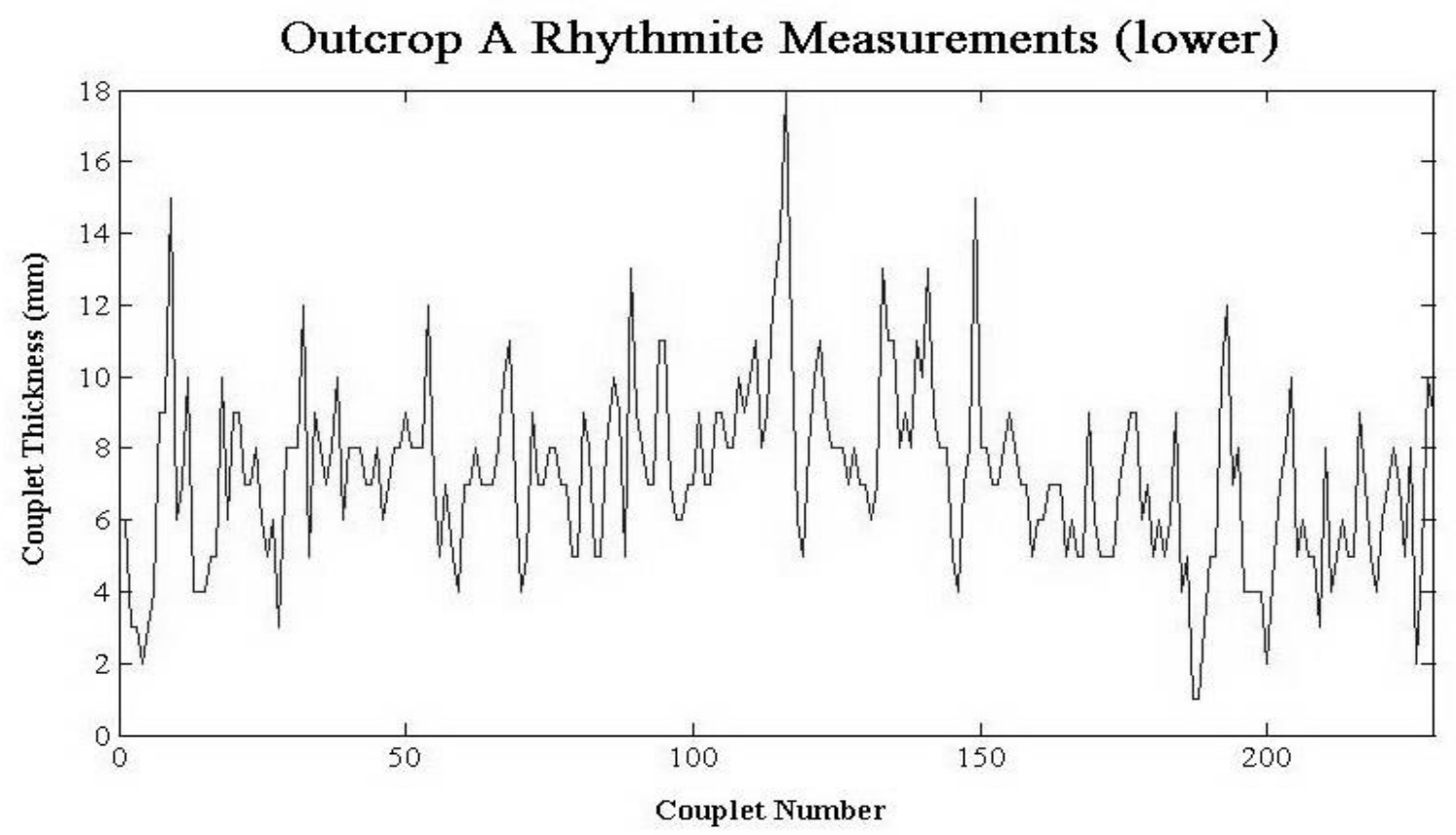

556 
Page 35 of 50

Figure 6

558

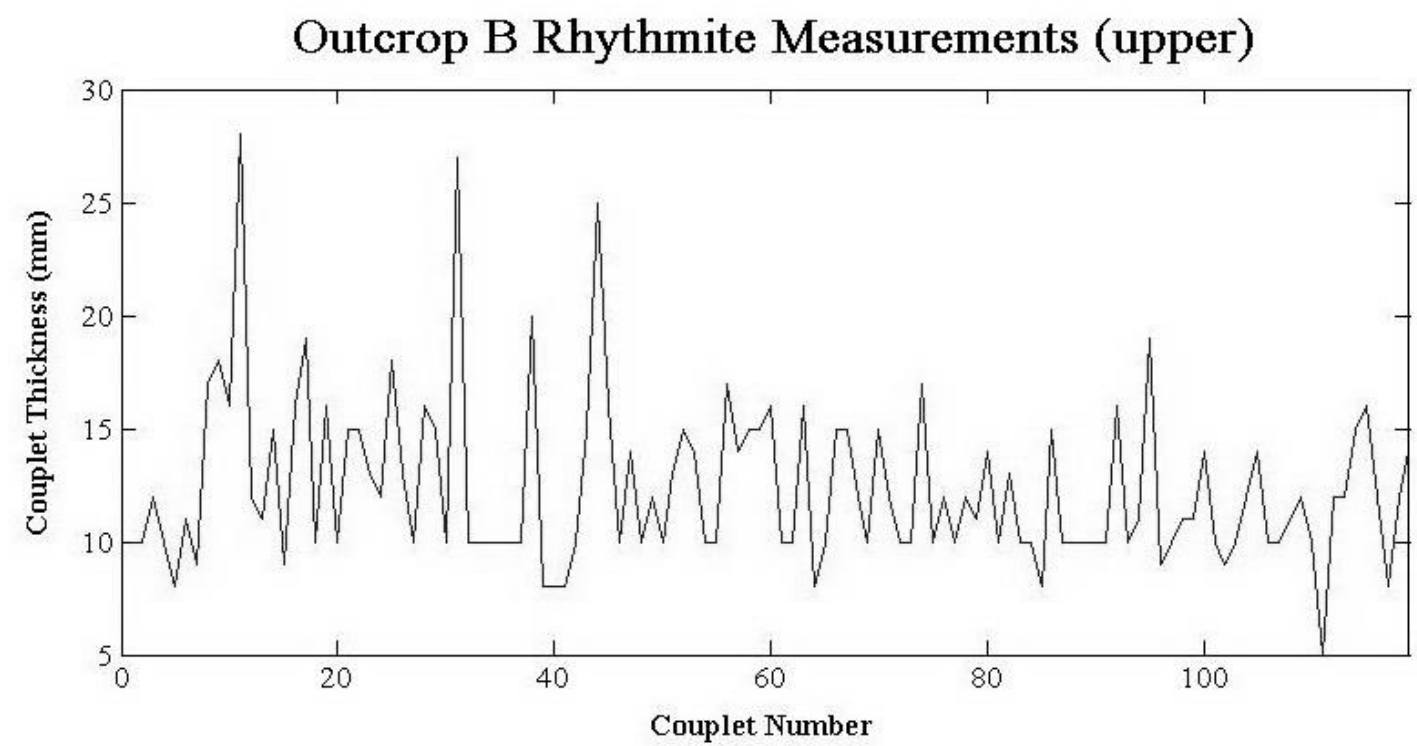

Outcrop B Rhythmite Measurements (lower)

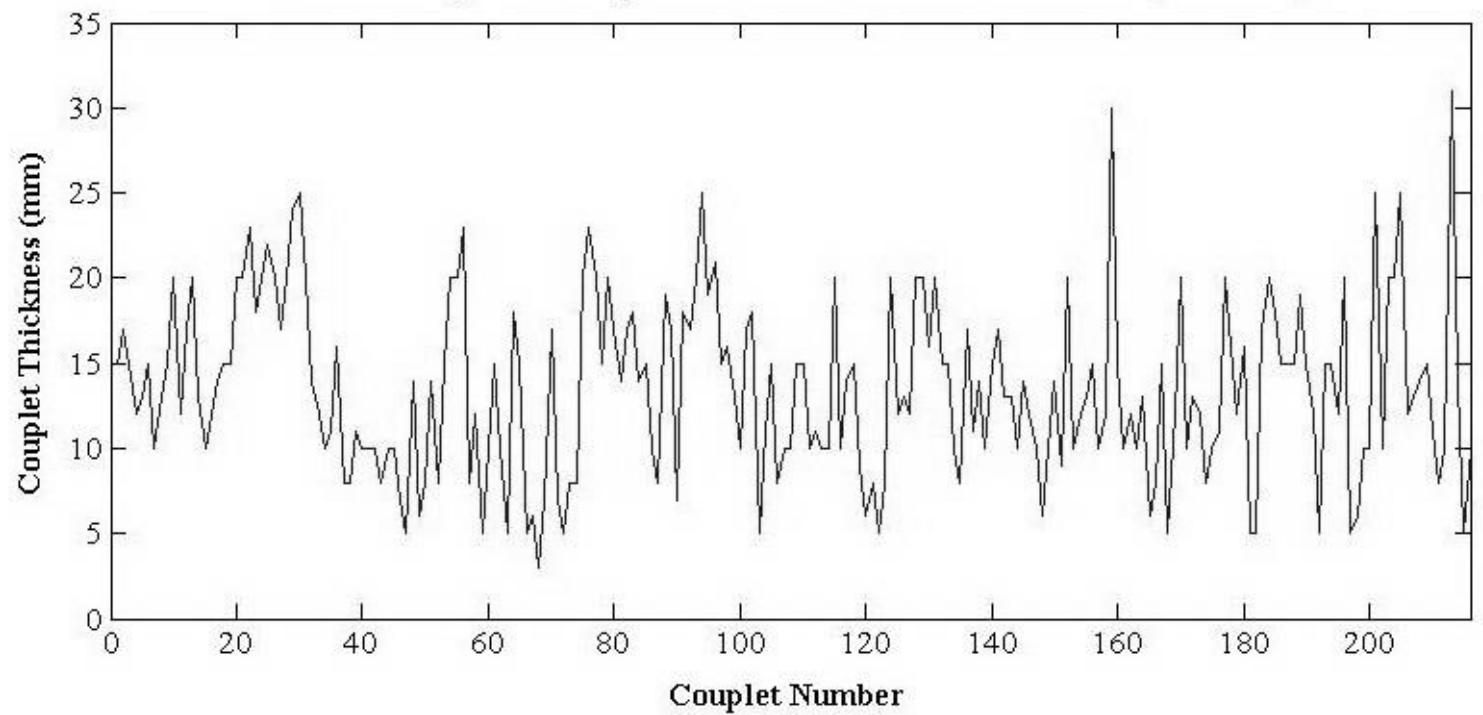

559 
Page 36 of 50

Figure 7

MTM Spectrum Hughes et al. (2003) Data

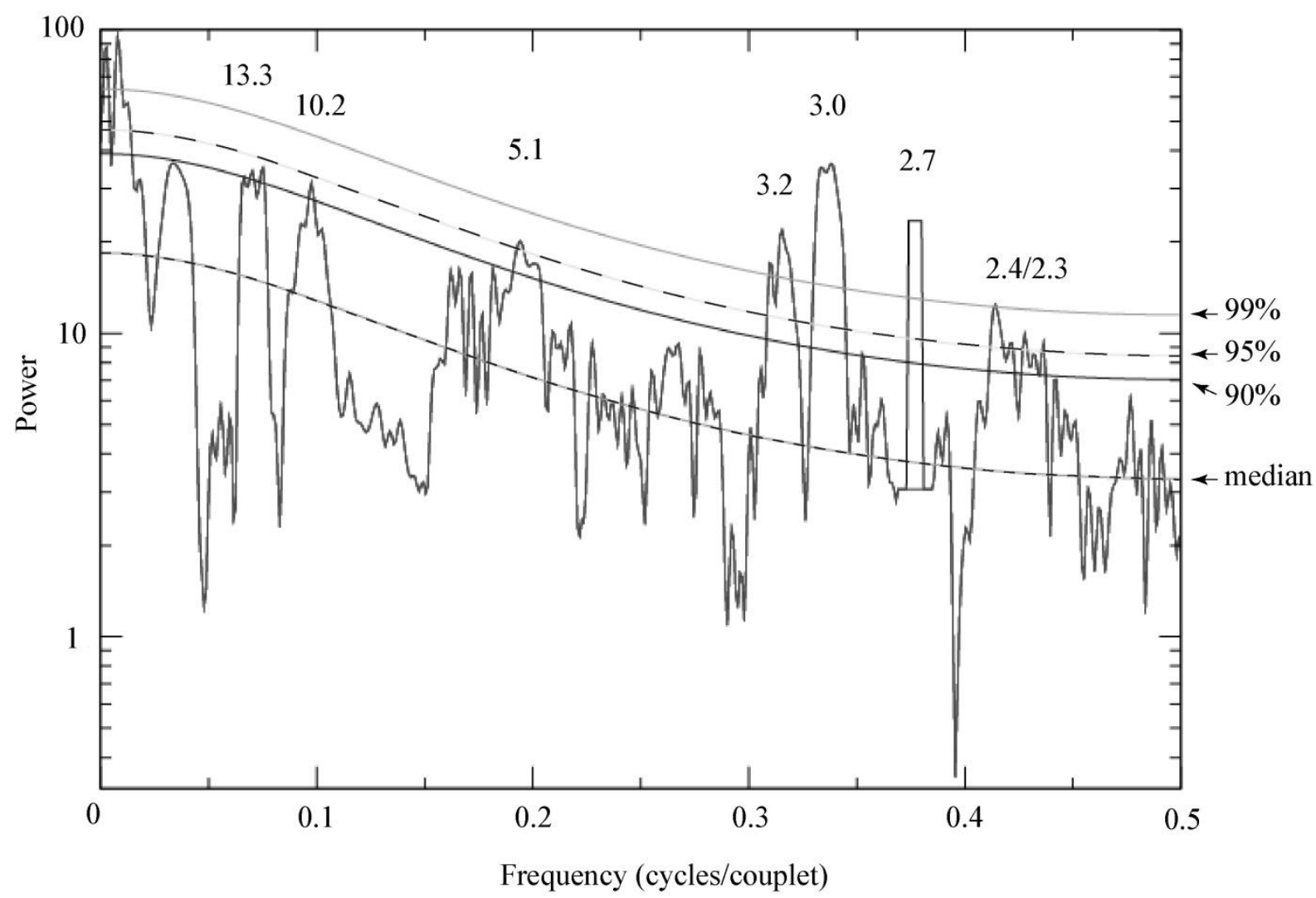




\section{Page 37 of 50}

564 Figure 8

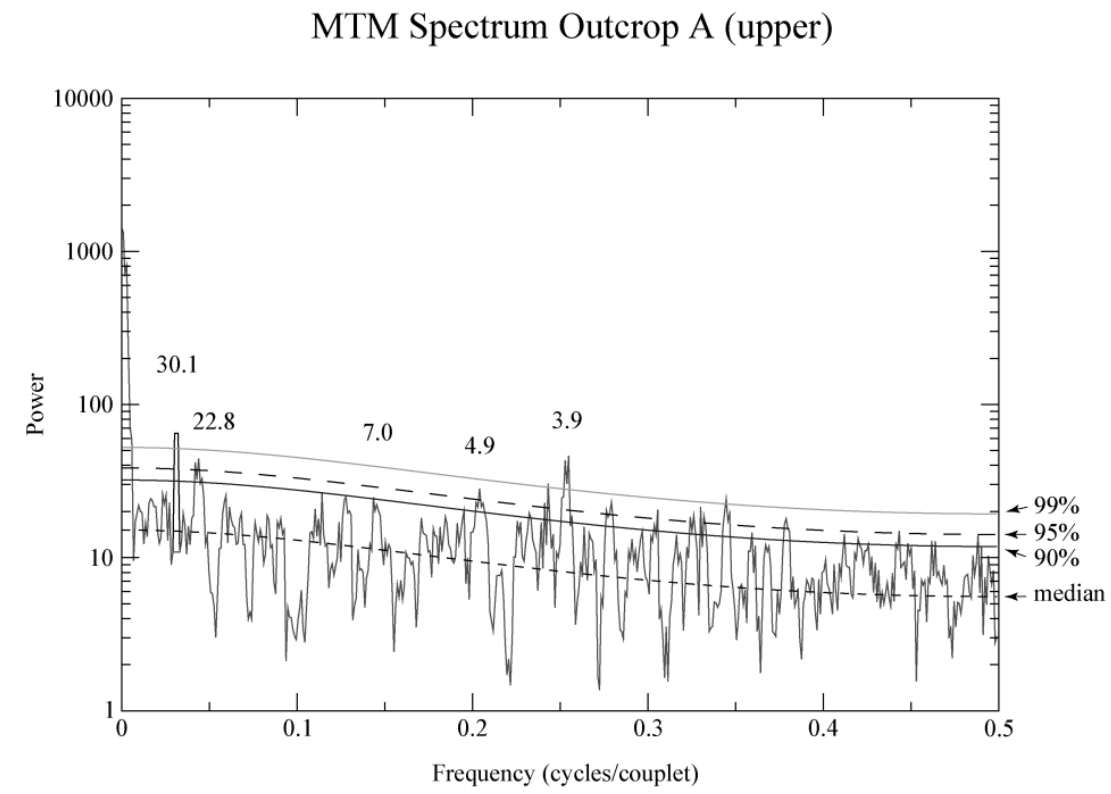

565

MTM Spectrum Outcrop A (lower)

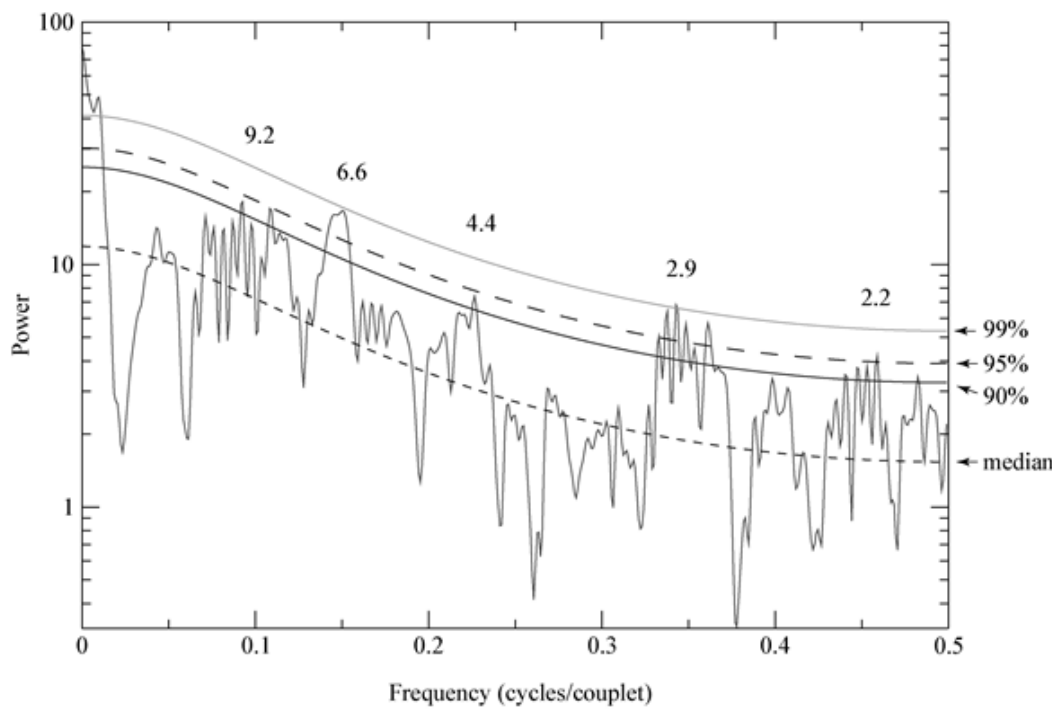




\section{Page 38 of 50}

Figure 9

MTM Spectrum Outcrop B (upper)

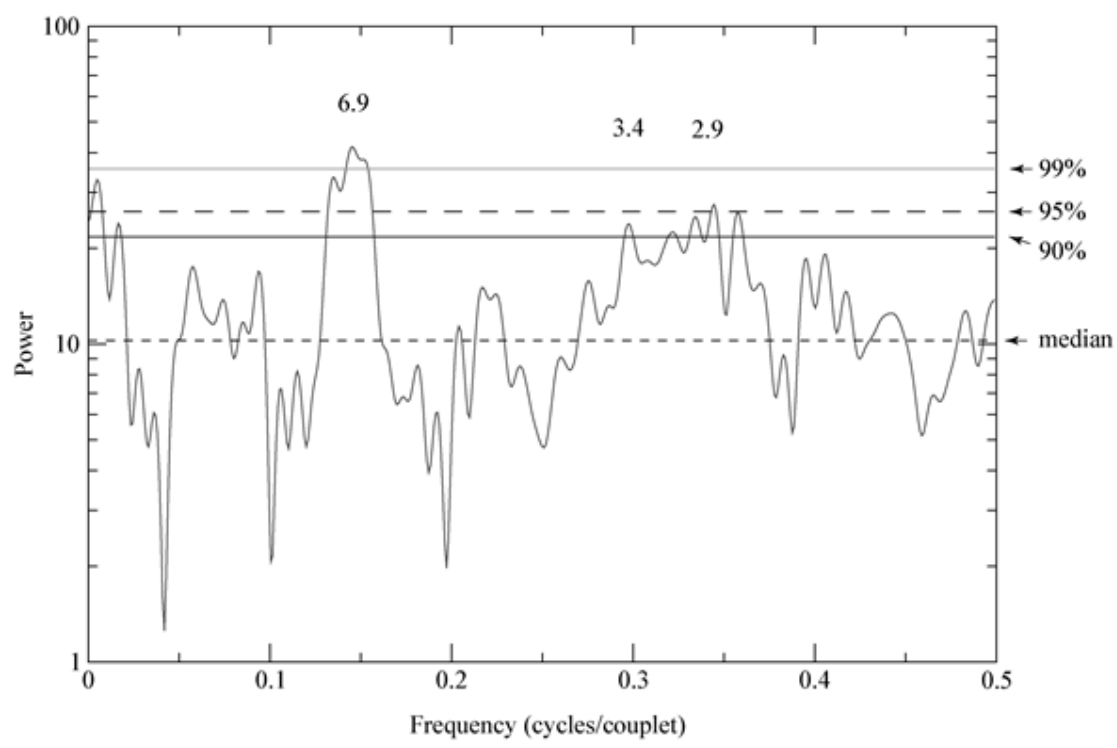

568

MTM Spectrum Outcrop B (lower)

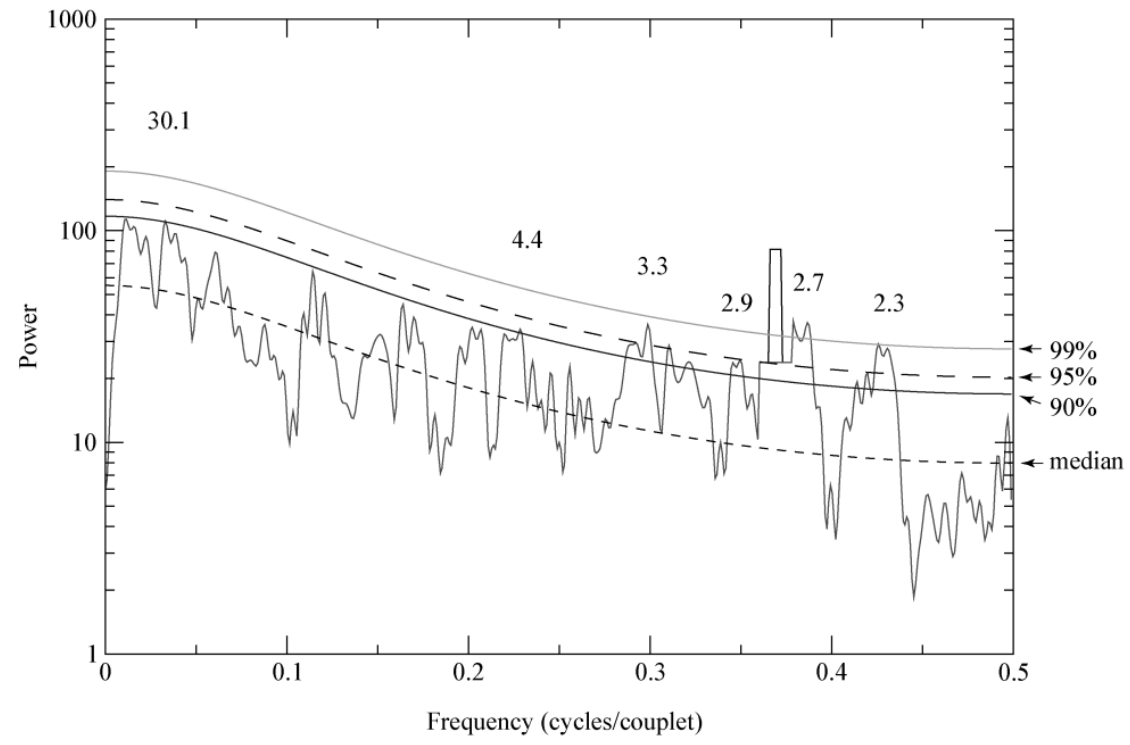


Page 39 of 50

\section{Table 1: Sedimentological characteristics of the upper Gowganda Formation in the study area (from Howe, 2015)}

572

\section{Lithofacies}

Siltstone-Claystone (1-15 m)

Siltstone layers: $1-4 \mathrm{~mm}$

Claystone layers: $1-30 \mathrm{~mm}$

\section{Conglomerate $(3 \mathrm{~cm})$}

\section{Sandstone $(10 \mathrm{~cm})$}

\section{Siltstone $(2.7 \mathrm{~m})$}

Siltstone layers: $1-50 \mathrm{~cm}$

Mudstone layers: $0.5-10 \mathrm{~cm}$

\section{Wavy Mudstone (35 m)}

\section{Siltstone (7 m)}

Coarse-grained siltstone: $15-50 \mathrm{~cm}$ Fine-grained siltstone: $5-40 \mathrm{~cm}$

\section{Characteristics \& Bedding Features}

Dark green to dark gray, alternating siltstoneclaystone beds; siltstone layers 1-2 mm thick increase to 3-4 $\mathrm{mm}$ thick up-section; claystone layers are 1-30 mm thick; granitic/gneissic pebbleto boulder-sized dropstones become less abundant up-section; local lenticular, pink, fine- to very finegrained wavy sandstone beds of starved ripples; grain size and irregular, non-rhythmic bedding increase up-section.

Pink granitic granules and pebbles in a grey argillaceous matrix.

Pink, massive, rippled contact with underlying and overlying claystone beds.

Siltstone beds $15-25 \mathrm{~cm}$ thick interbedded with rhythmic intervals of siltstone and mudstone; rhythmic sequences are $8-10 \mathrm{~cm}$ thick, and are composed of beds of siltstone averaging $1.5 \mathrm{~cm}$ thick and mudstone laminations up to $1 \mathrm{~cm}$ thick.

Thin beds of wavy, parallel mudstone. Measured wavelengths between 1.6 and $4.5 \mathrm{~m}$ and $13-22 \mathrm{~cm}$ high.

Grey, thin, planar bedded, coarse- and fine-gained siltstone couplets that range from 3-31 mm thick.

\section{Mechanisms \& Processes}

Rhythmites represent recurring flux in transport energy: lower energy results in claystone layers, and higher energy results in siltstone layers. Dropstones represen ice-rafted debris. Lenticular sandstone beds resulted from irregular increase in transport energy during periods of intense precipitation or distal jökulhlaups (glacial lake outburst floods).

Planar laminated within siltstone-claystone lithofacies.

Reworked, locally available sand.

The intercalated siltstone and mudstone beds indicate variations in sedimentation rate, whereas thicker siltstone beds indicate a steady sedimentation rate.

Very fine grain size indicates low transport energy and greater distance from glacier.

Fluctuating current energy conditions; Increasingly rapid deposition is indicated up-section by flame structures in the finegrained siltstone, and lenses in the coarsegrained siltstone layers.

\section{$\underline{\text { Interpretation \& Setting }}$}

Distal deltaic deposits.

Iceberg-dumped debris

Delta front sand sheet associated with delta progradation.

Short term, possibly diurnal, stops and starts in glacial melting that could be associated with a cycle of freezing conditions at night and melting conditions during the day. Summer melt cycle resulted in continuous, silty sedimentation. Possible delta lobate deposit.

Possible overbank or inner bay floor deposits influenced by waves.

Possible fluvial deposits that were ransported to a medial delta front. 
Table 2: Summary of spectral analysis results from this study, and the Hughes et al. (2003) study

\begin{tabular}{|c|c|c|c|c|c|}
\hline Outcrop A (lower) & Outcrop A (upper) & Outcrop B (lower) & Outcrop B (upper) & Hughes $(\mathrm{MTM})^{2}$ & Hughes (published) ${ }^{1}$ \\
\hline$n=229$ & $\mathrm{n}=585$ & $\mathrm{n}=216$ & $\mathrm{n}=119$ & $\mathrm{n}=256$ & $\mathrm{n}=256$ \\
\hline \multirow[t]{3}{*}{ period (couplets) } & period (couplets) & period (couplets) & period (couplets) & period (couplets) & period (couplets) \\
\hline & 31 & 30.1 & & & \\
\hline & 22.8 & & & 13.3 & 14.3 \\
\hline 9.2 & 8.8 & & & 10.2 & $10.7,9.9$ \\
\hline 6.6 & & & 6.9 & & 6.1 \\
\hline 4.4 & $3.0-4.9$ & $3.3-4.4$ & $3.0-3.4$ & $3.0-3.2,5.1$ & $3.0-5.0$ \\
\hline $2.2-2.9$ & $2.3-2.9$ & $2.3-2.9$ & $2.8-2.9$ & $2.3-2.9$ & $2.3-2.9$ \\
\hline
\end{tabular}

Results are shown for detected signal periods (in couplets).

Results from the Hughes et al. (2003) study as published ${ }^{1}$, and as produced by the MTM Toolkit ${ }^{2}$, are shown with this study's results.

Table 3: Comparison of this study with similar studies conducted in the Great Lakes region.

\begin{tabular}{lllc}
\hline \multicolumn{1}{c}{ Study } & \multicolumn{1}{c}{ Deposits } & ENSO & NAO \\
Godsey et al. (1999) & Lake Huron sediments & $3-7$ years & n/a \\
Rittenour et al. (2000) & Lake Hitchcock sediments & $3-7$ years & n/a \\
Breckenridge (2007) & Lake Superior sediments & $3-6$ years & $6-7$ years \\
Hughes et al. (2003) & Gowganda Fm sediments & $3-6$ years & $6-7$ years \\
This study (2016) & Gowganda Fm sediments & $3-6$ years & $6-7$ years \\
\hline
\end{tabular}

If the period of deposition is interpreted to be one year then spectral signals in the 3 - 6 year range may result from oceanic oscillations similar to the El Niño Southern Oscillation (ENSO) and periods of $6-7$ years may indicate the influence of an oceanic oscillation similar to the North Atlantic Oscillation (NAO). 


\section{Page 41 of 50}

\section{Colour Images for On-line Publication Only}


Page 42 of 50

$578 \quad$ Figure 1
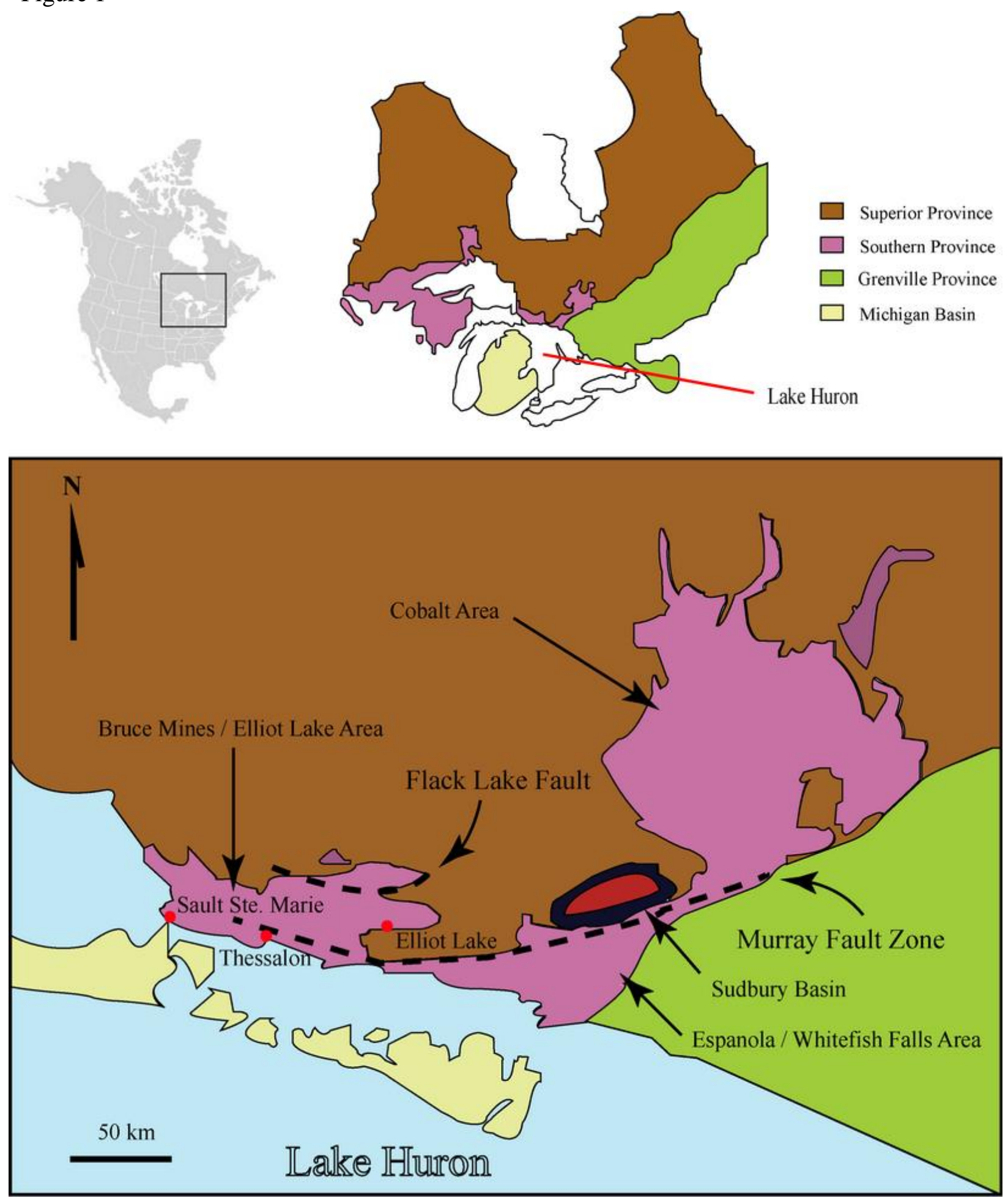
Figure 2

\section{Huronian Supergroup}

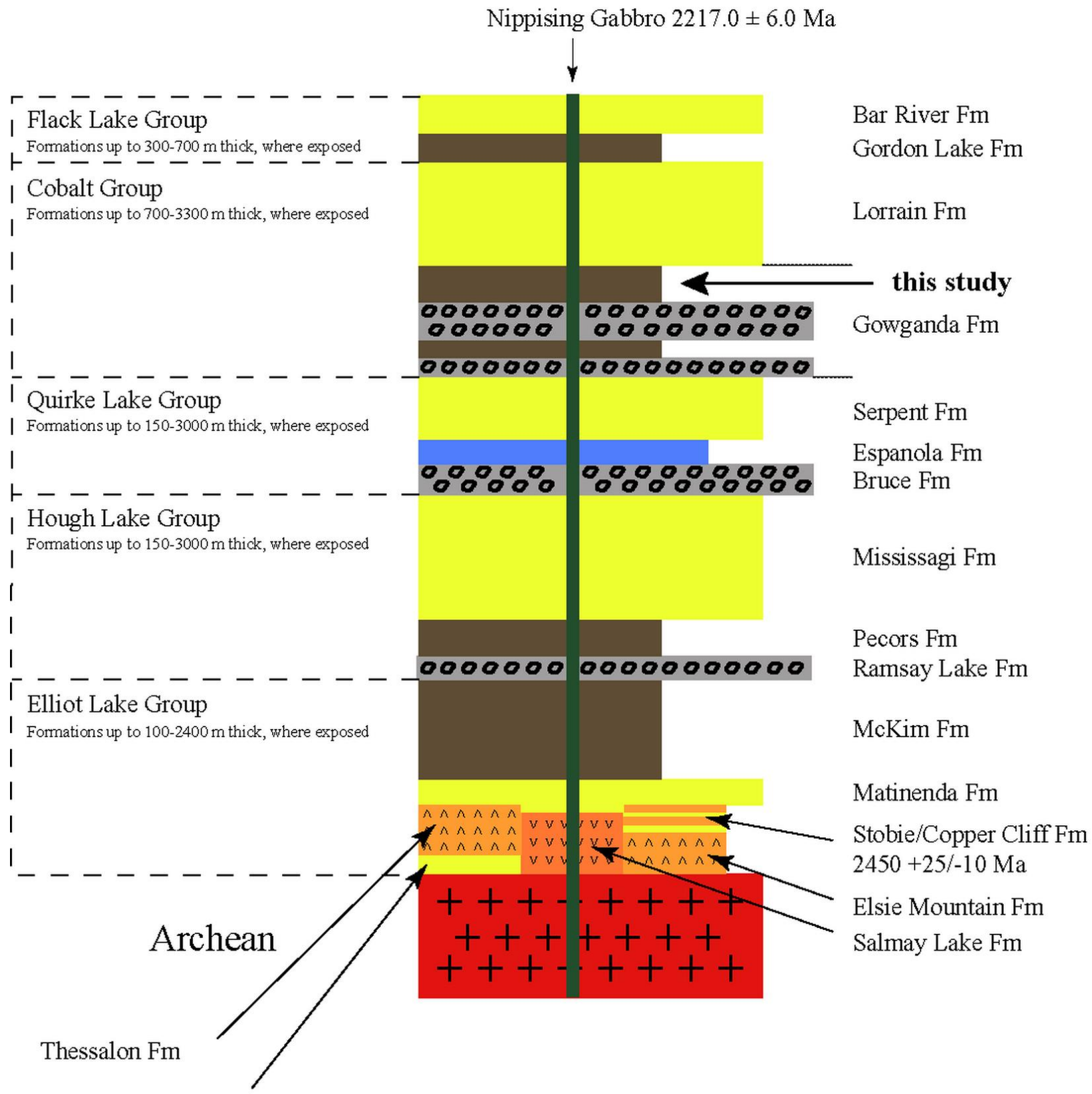

Livingstone Creek Fm 
Page 44 of 50

$583 \quad$ Figure 3

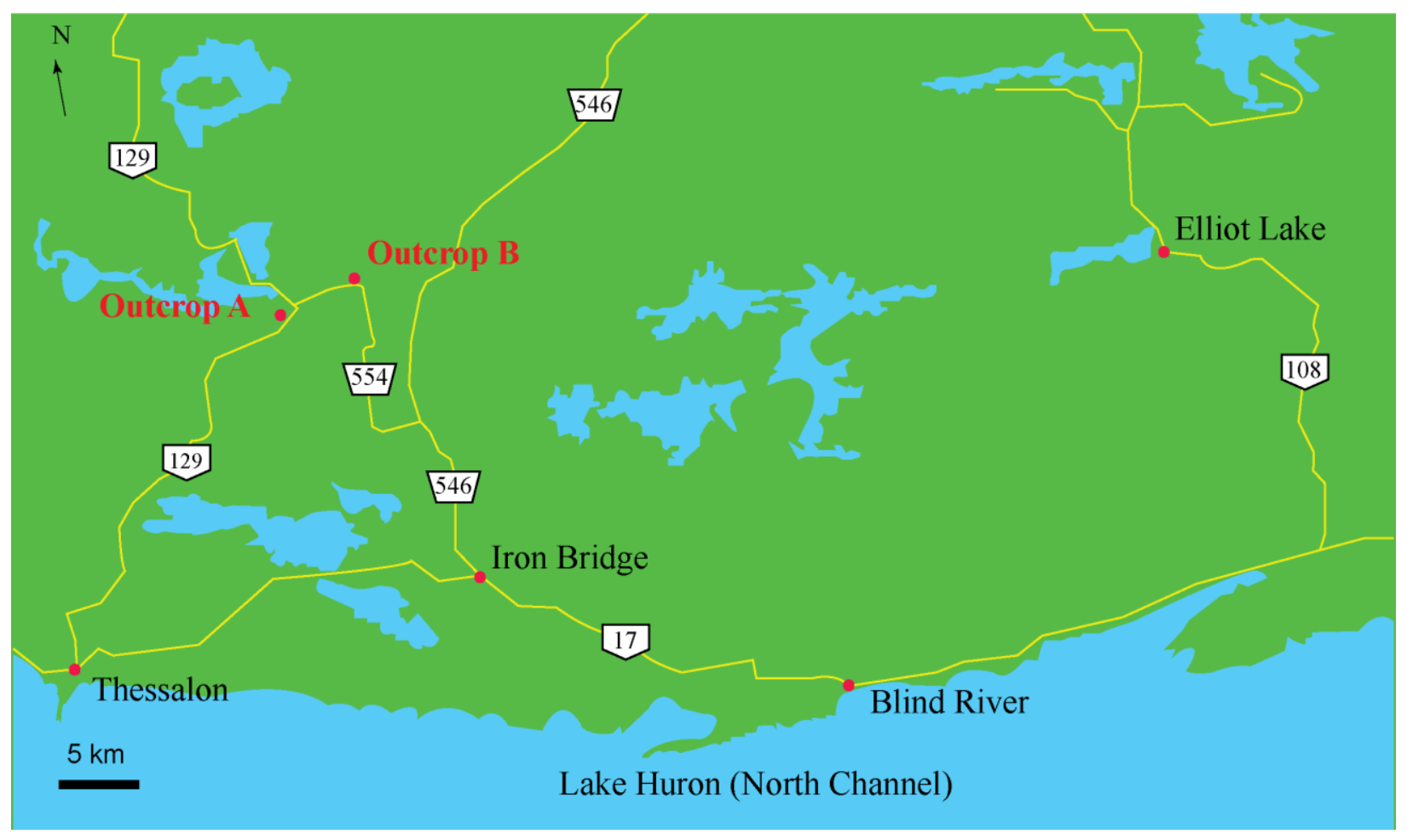

585

586 
Page 45 of 50

$587 \quad$ Figure 4

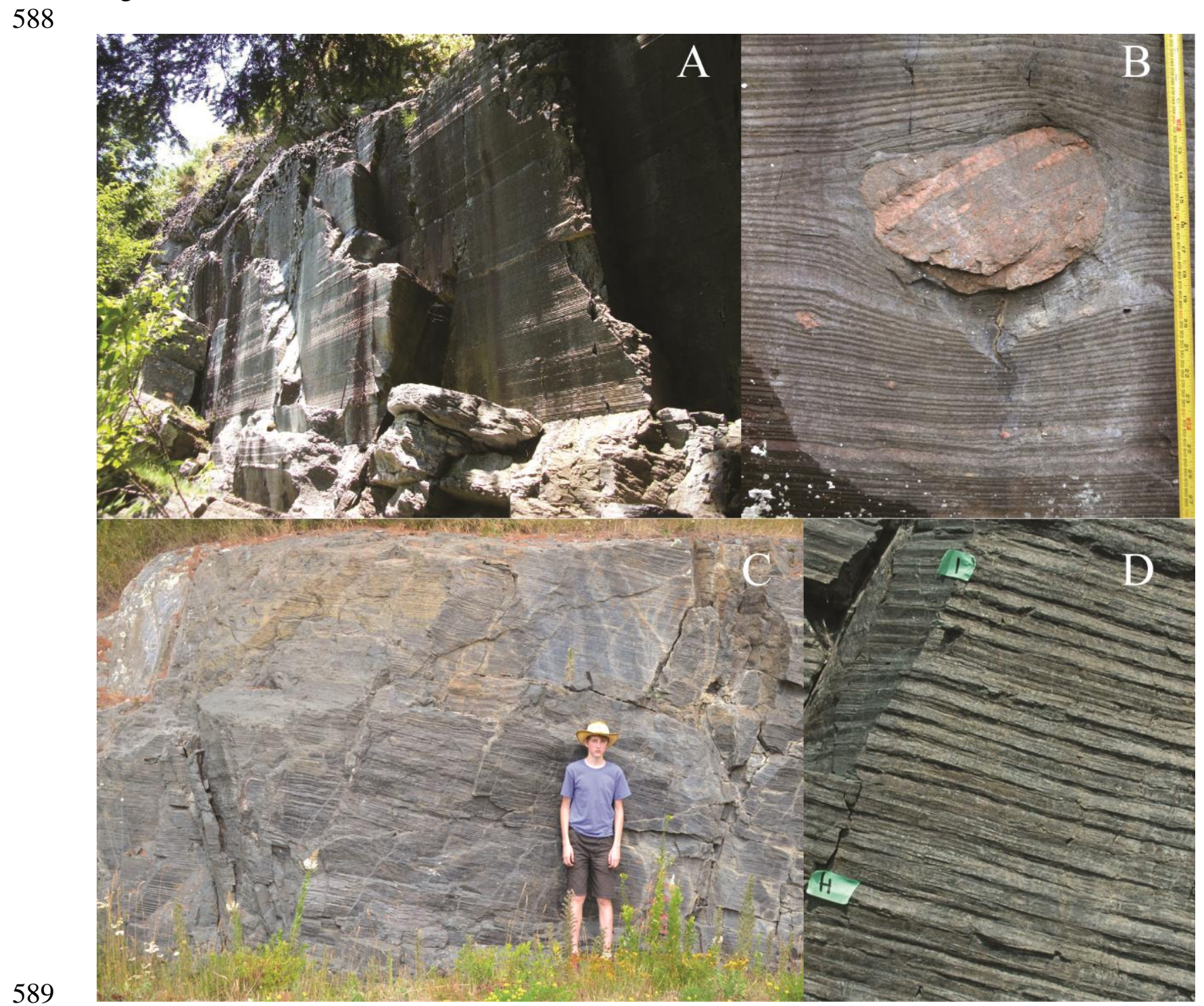

590 
Page 46 of 50

591

Figure 5

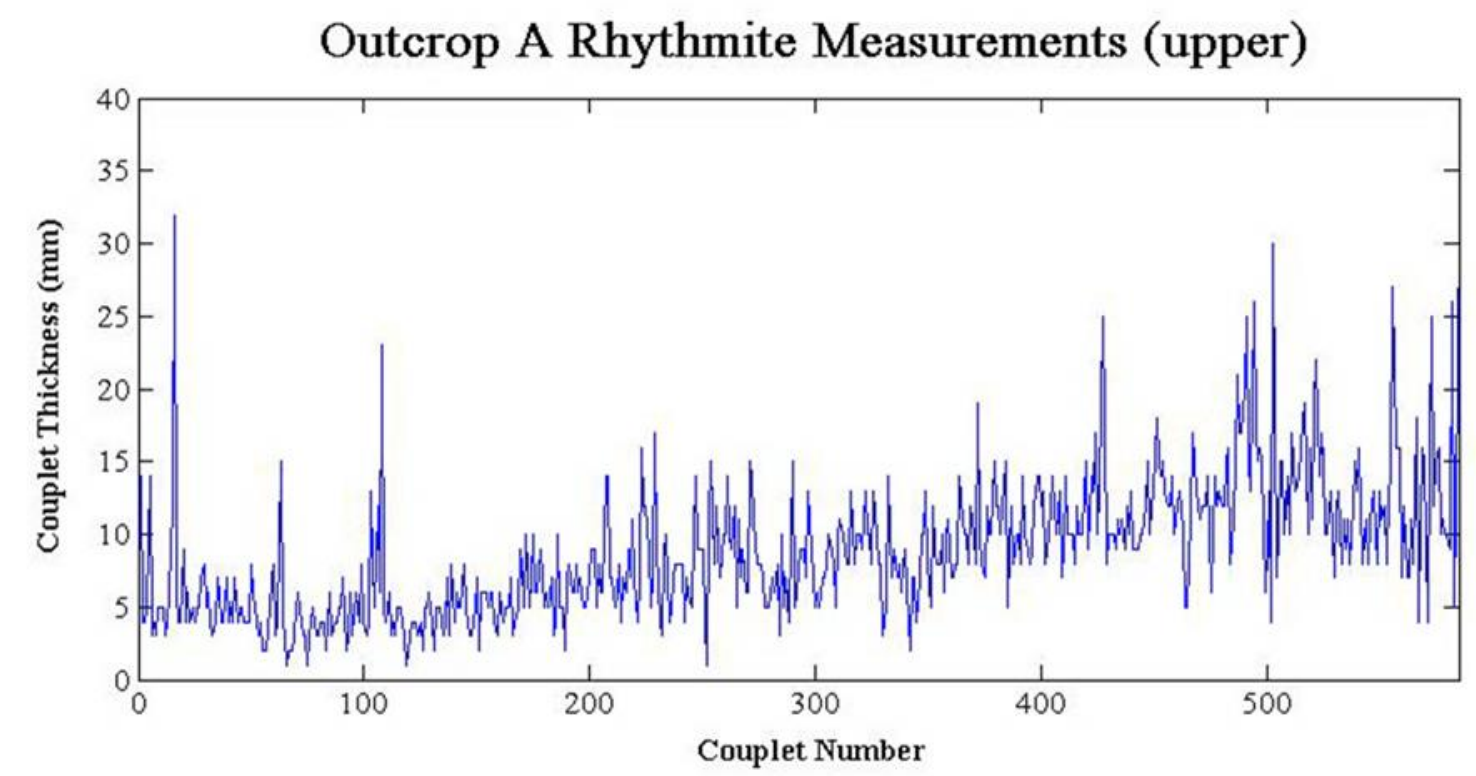

592

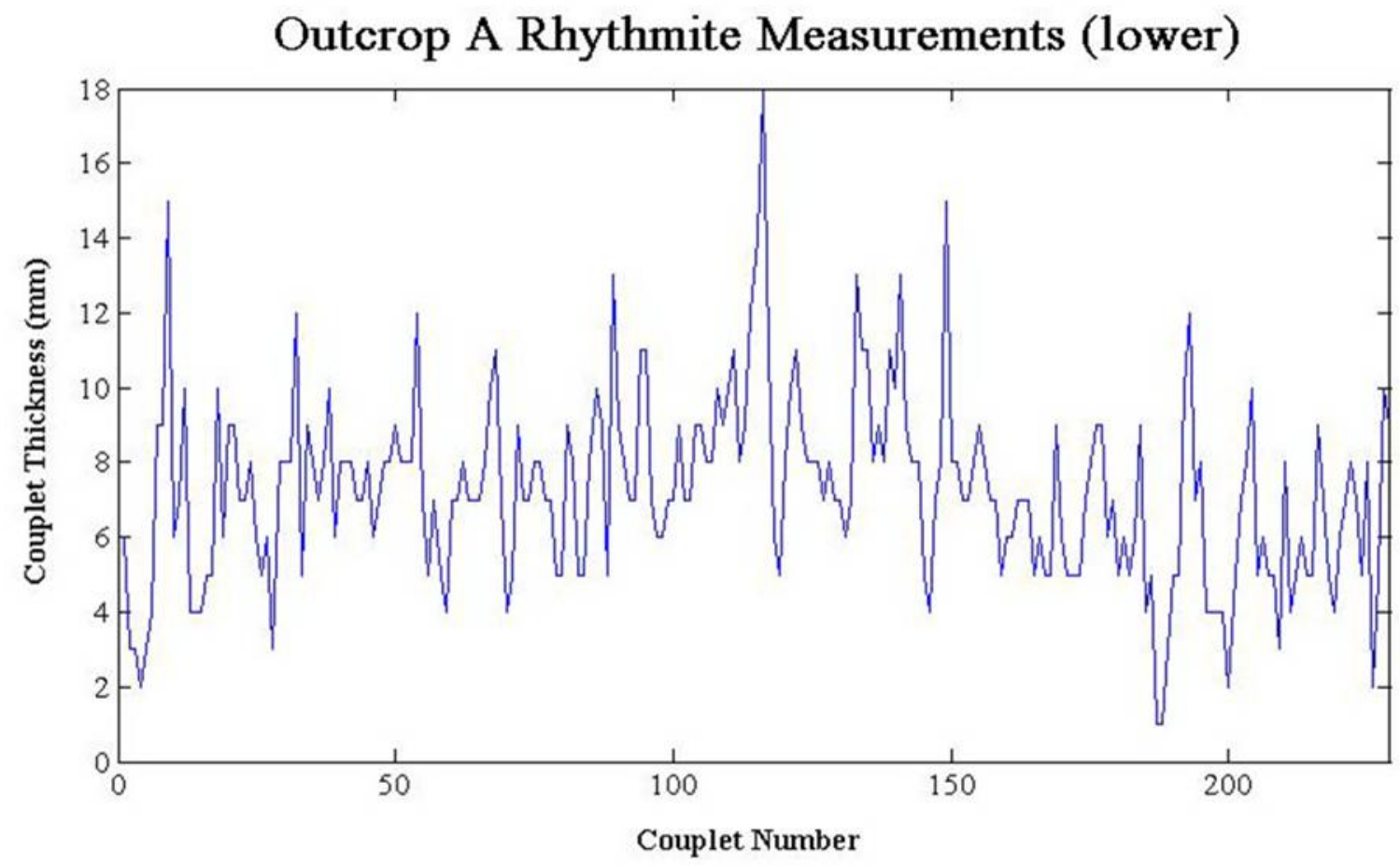

593 
Page 47 of 50

594

Figure 6

595
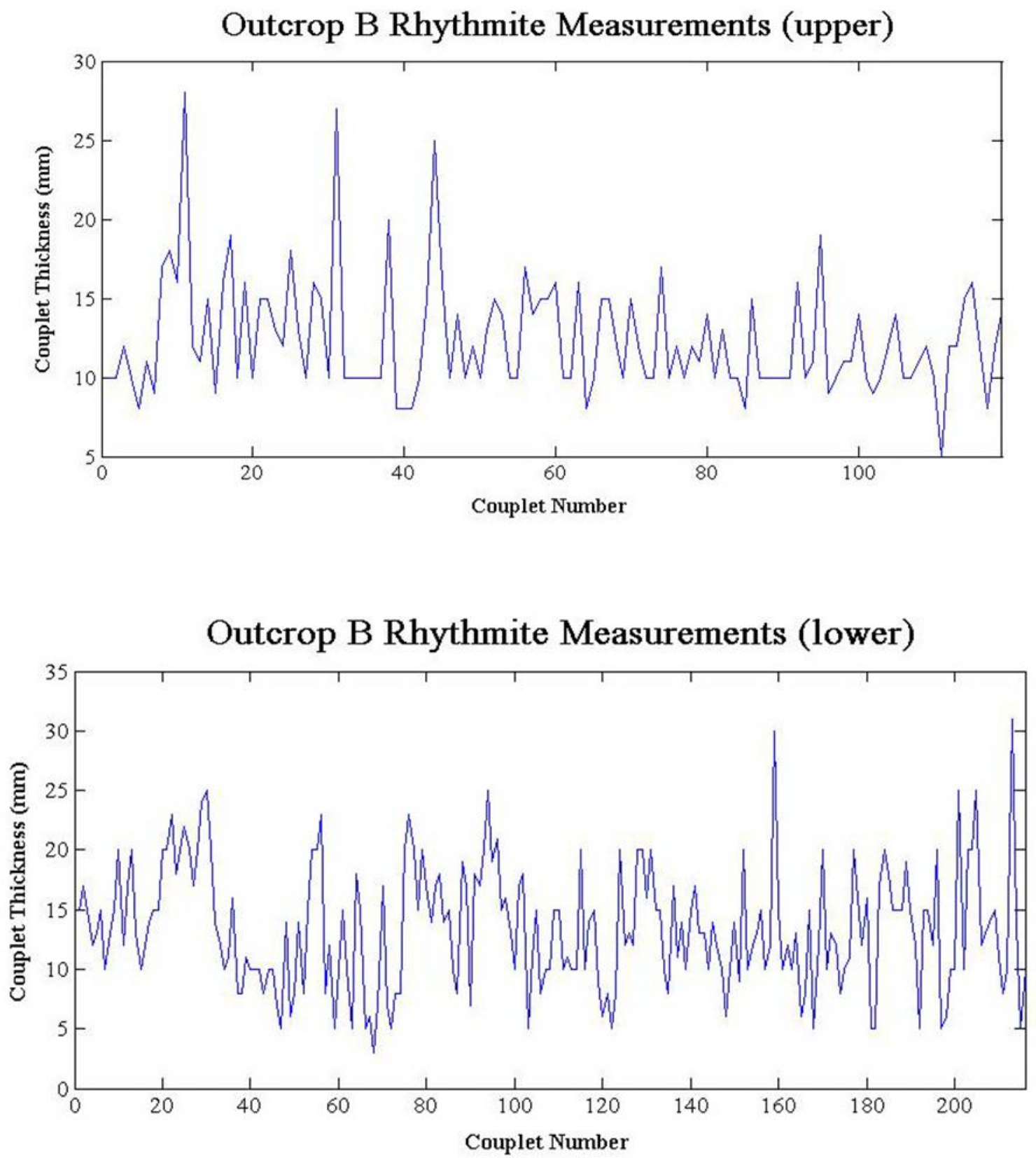

596

597 
Page 48 of 50

598

Figure 7

MTM Spectrum Hughes et al. (2003) Data

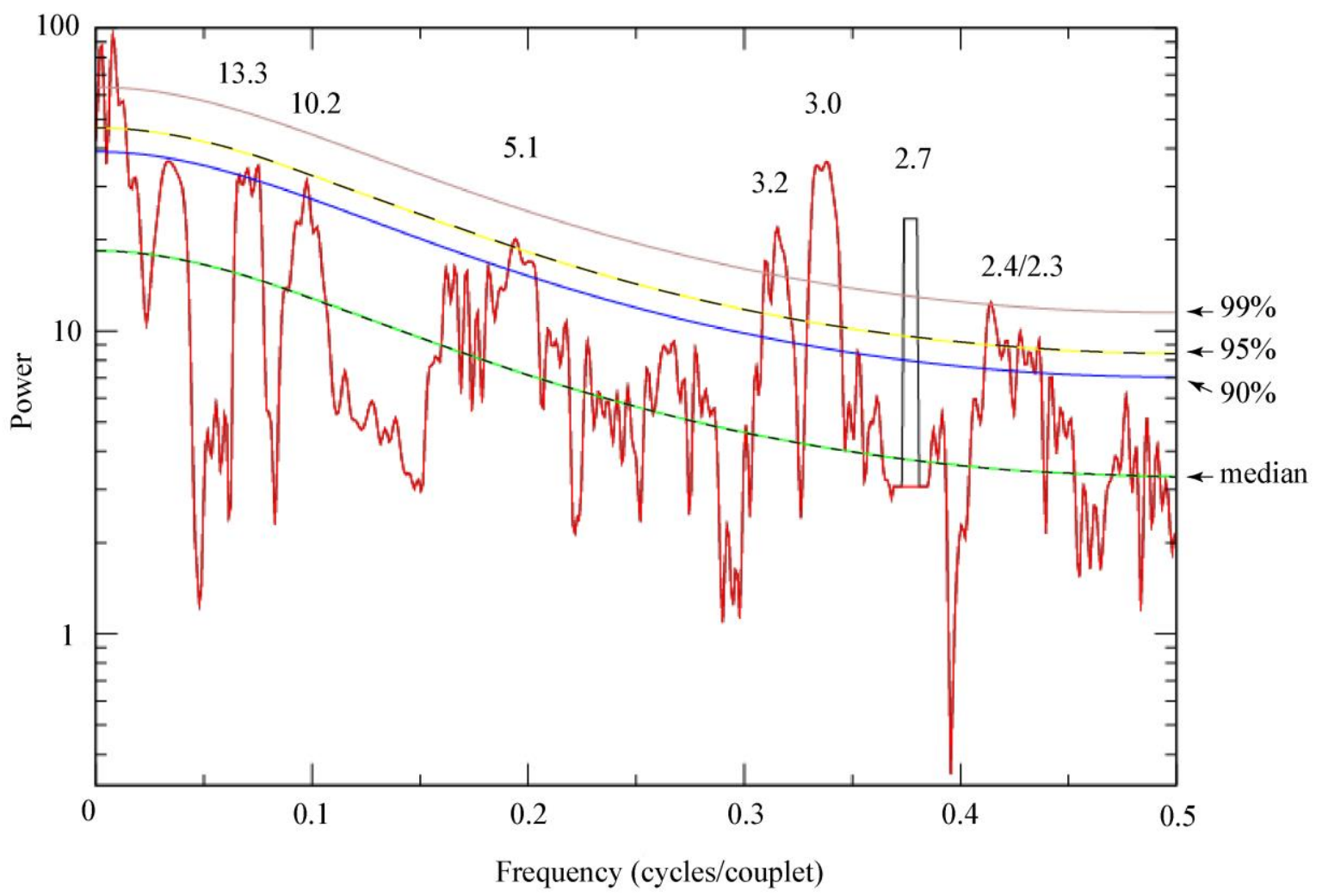

599

600 


\section{Page 49 of 50}

601

Figure 8

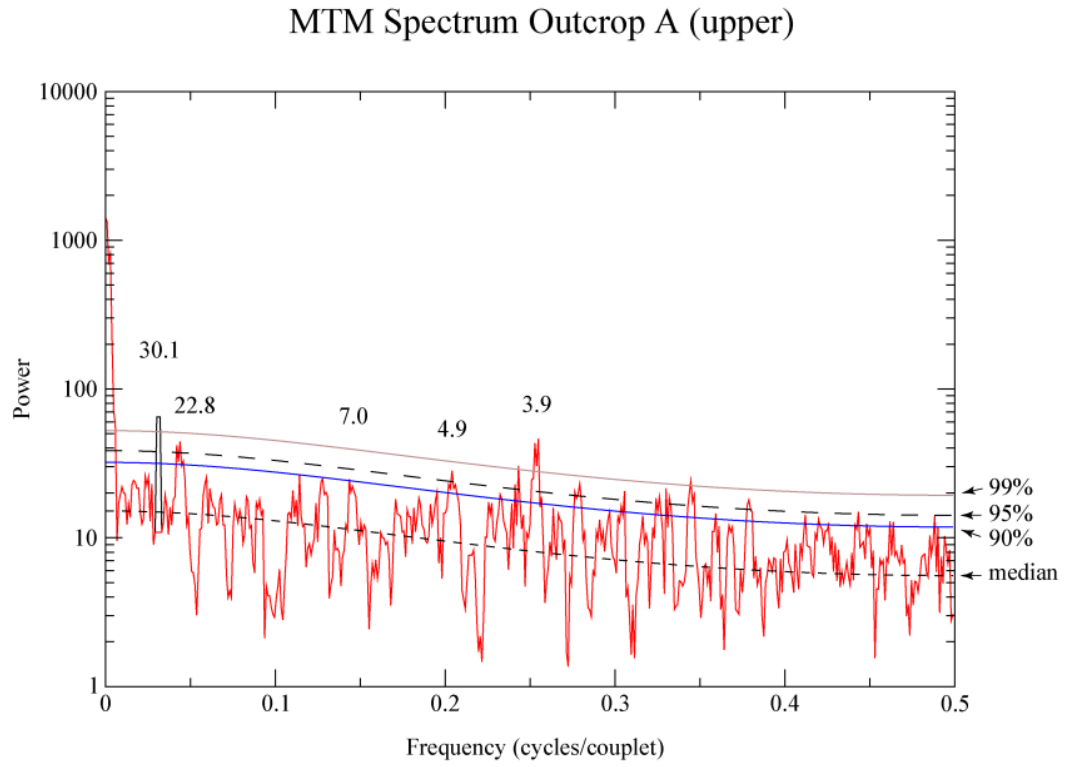

602

MTM Spectrum Outcrop A (lower)

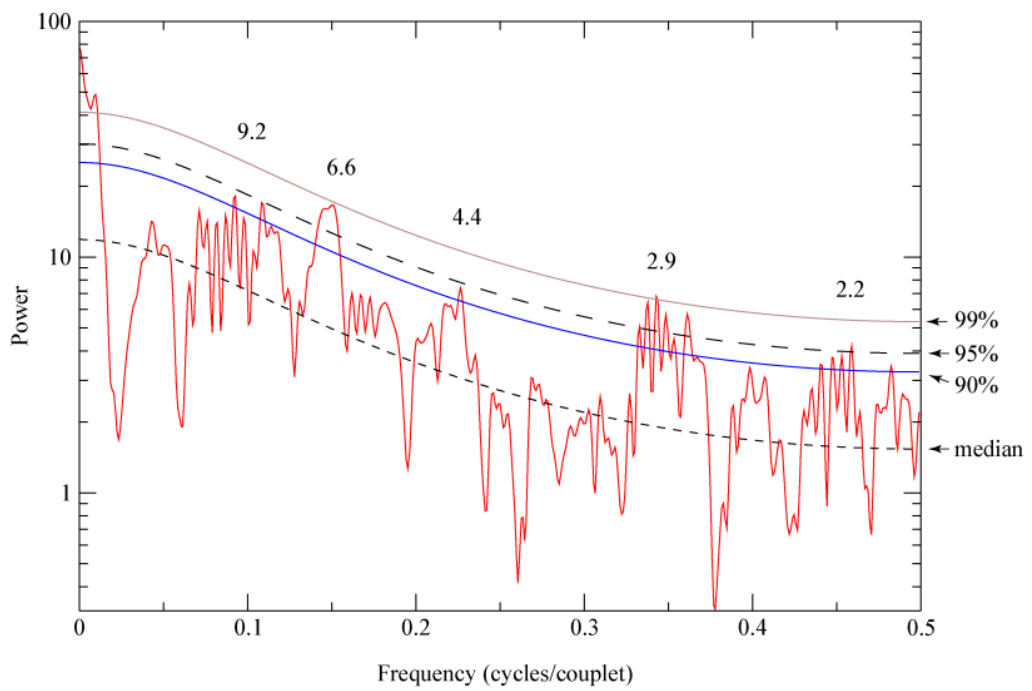




\section{Page 50 of 50}

604 Figure 9

MTM Spectrum Outcrop B (upper)

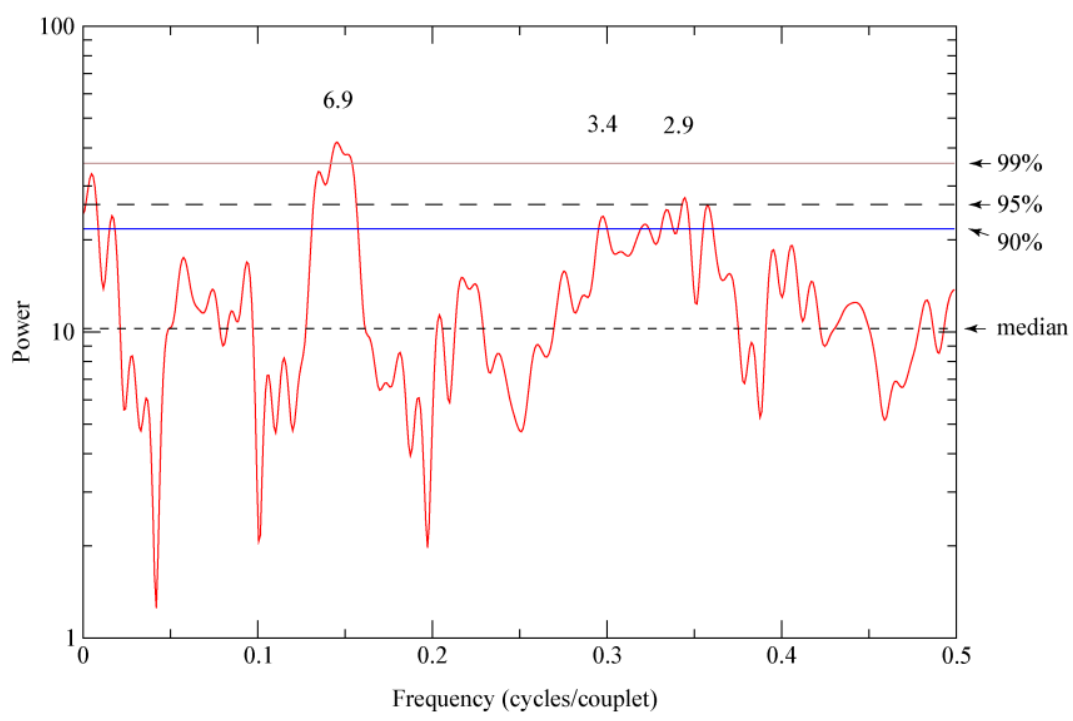

605

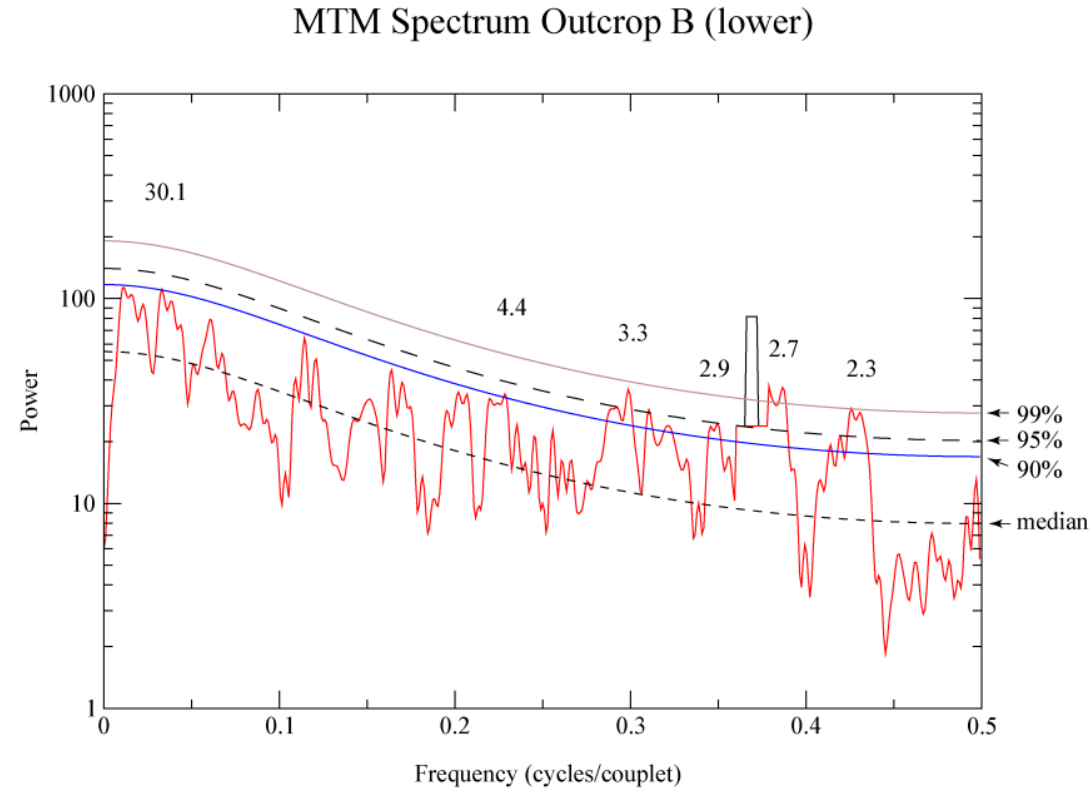

606 